QL

444

C73M36

1910

INVERT.

ZOOL 



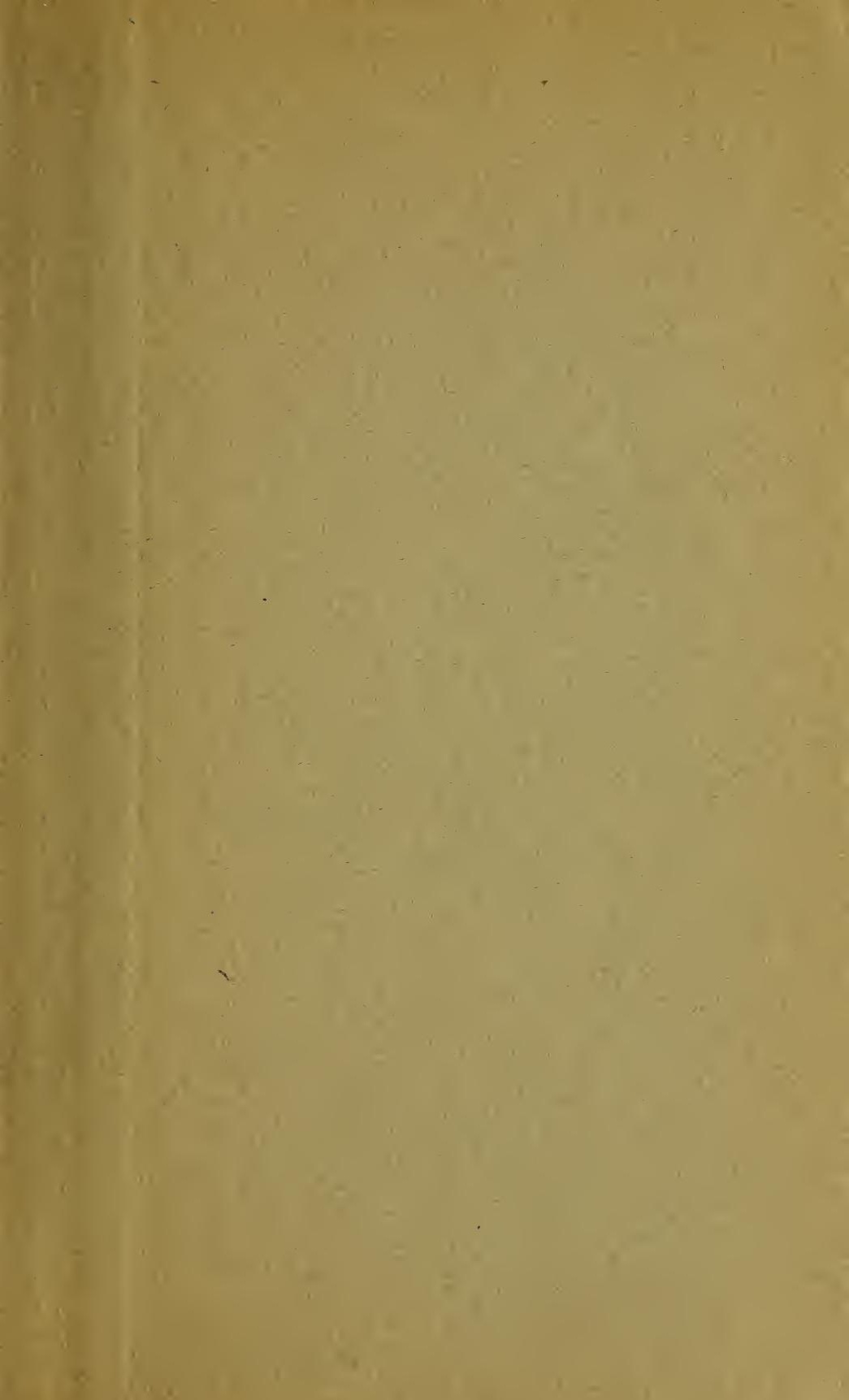





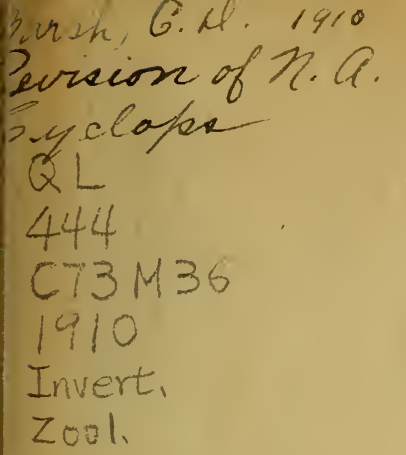

\title{
A REVISION OF THE NORTH AMERICAN SPECIES OF CYCLOPS.
}

\author{
C. DWIGHT MARSH.
}

Reprinted from Volome XVI, Part II, of the Transactions of the Wisconsin ACademy of Sciences, Arts, and Letters.]

\section{[Issued April, 1910.]}

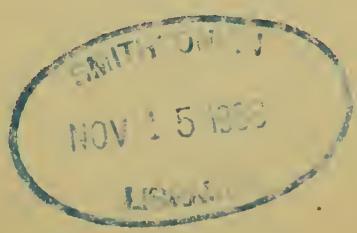





\section{A REVISION OF THE NORTH AMERICAN SPECIES OF CYCLOPS.}

C. DWIGHT MARSH.

As collections are made more and more widely from all parts of the world and as these collections are studied more thoroughly, it becomes increasingly evident not only that the genus of Cyclops is distributed over the whole world, but that individual species have an exceedingly wide distribution. Many of the species which have been described as peculiar to America have been clearly shown either to be identical with species in Europe or merely varieties of those species. Little by little it has been necessary to reduce to synonyms the names which have been proposed for American species. It can not yet be said that all American species are identical with those in Europe, but it is very evident that most of them are. Most of the species of Cyclops have wide limits of variation, and it is these variations which, at a time when the knowledge of the entomostraca was imperfect, lead to the introduction of many new names for species which we now know are only varieties.

This leads to a great deal of confusion when students of anatomy or plankton, who may have no particular interest in a systematic knowledge of Entomostraca, attempt to name the species which they are studying. So great is this confusion that many students of plankton do not attempt to use specific names, but simply describe the distribution of "Cyclops." This is extremely unfortunate, for the species of Cyclops have very different habits and a discussion of plank- 
ton with all the species of this genus grouped together has very little value so far as Entomostraca are concerned. It may be a matter of doubt whether the general student of Zoology is ever likely to determine the species of Copepoda easily, as special training is almost necessary for such work. But, even if one had patience and a willingness to do the necessary work, authoritative publications have not been arailable. Probably the majority of students of North American Entomostraca refer to Herrick and Turner's work because it is more comprehensive than any other work published. This is now, however, pretty thoroughly out of date, and it is rery aggravating to a student to feel that his book of reference is unreliable.

A much more accurate paper is that of E. B. Forbes (Forbes '97) and it seems to me that the real value of this paper has never been recognized. It is now ten years since Forbes's paper was published and additions have been made to our knowledge of the genus, and facts which lead to a reconsideration of some of his statements.

It has seemed to the anthor that the time has come when a paper which would accurately present our knowledge of the genus today, would be of real assistance to those students who have anything to do with Entomostraca. There is really very little to add that is new from the standpoint of the species maker, only one new species is suggested, but it is worth while to know what it is best to call the old species which have been recognized under different names.

In preparing this paper we have accepted the work of Schmeil as authoritative for European species. Sometime it is to be hoped that equally thorough work can be done for our American species, but it does not seem wise to undertake it at present. Our knowledge of the distribution of species in America has been very much enriched in the past few years, but nothing like thorough work has been done. The present paper is based on collections made from the northern Canadian provinces to Mexico and the West Indies, and from the Atlantic to the Pacific, but vastly the most complete collections have been made in the Mississippi Valley. 
It will be noticed, doubtless, that the sub-generic names that have been adopted by some authors have not been recognized. The species of Cyclops certainly fall into certain groups, but it is the feeling of the author that our knowledge of the relationships of the species in these groups is not yet sufficiently wide to warrant the formality of fixed sub-generic names. I must confess to a dislike of multiplying names in systematic work, and do not enjoy sub-generic names under any circumstances, preferring to avoid them when practicable. The number of species in the genus Cyclops is not very large, and the addition of subdivisions in our present state of knowledge is distasteful to me.

A considerable number of figures has been used to illustrate the paper, enough, it is hoped, to make clear the diagnoses. The synopsis is not published as a final production. No one appreciates better than the author how much work remains to be done on these forms. On the other hand the paper is the result of accumulations of material covering many years. A large number of slides have been made from these collections, and while the work is confessedly incomplete, it is perhaps due to others who are interested in these animals to make some of the results available for use. The systematic study of entomostraca is, at best, a very laborious process, and it is hoped that this brief paper may help in lightening the labors of others who may wish to use specific names for the Cyclopidae.

The key is based on the characteristics of mature females and includes only those species which are recognized members of the American fauna.

6-S. \& A. -3 


\section{KEY TO SPECIES OF CYCLOPS FOUND IN NOITH AMERICA.}

Antennae composed of 17 segments

Fifth foot composed of one segment, armed with one spine and two long setae, —a large species of dark color,

Fifth foot composed of two segments,

Second segment of fifth foot armed with seta and short spine

Second segment of fifth foot armed with two setae, The second segment of the fifth foot is elongate, its length as much as twice its width, the seta of the inner distal angle spine-like, less than one half the length of the outer seta, bicuspidatus

The second segment of the fifth foot is shorter, length less than twice its width, armed with two nearly equal setae,

The seventeenth antennal segment is armed with a serrate hyaline plate,

Leuckarti

The seventeenth antennal segment is not armed with a hyaline plate,

The second segment of the fifth foot is armed with three setae

The twelfth antennal segment has a sensory club, the egg-sacs stand out from the abdomen, the hyaline plate of the seventeenth antennal segment is serrate, or smooth,

The twelfth antennal segment has a sensory hair, the egg-sacs lie close to the abdomen, the hyaline plate of the seventeenth antennal segment is deeply notched,

Antennae composed of sixteen segments, fifth foot of three segments,

modestus

Antennae composed of twelve segments, fifth foot of one segment.

Fifth foot armed with three setae, rami of swimming feet of three segments.

Furca of variable length, armed externally with a row of spines, found almost everywhere.

serrulatus

Furca short, without spinous armature, a small limnetic species,

Fifth foot armed with one seta, rami of swimming feet of

two segments,

varicans

Antennae composed of eleven segments,

Rami of swimming feet composed of three segments,

Rami of swimming feet composed of two segments,

Antennae composed of eight segments,

Antennae composed of six segments,

phaleratus

bicolor

fimbriatus

aequoreus 


\section{CYCLOPS ATER HERRICK.}

Plate, LXXII. figs. 1 to 6 and 9.

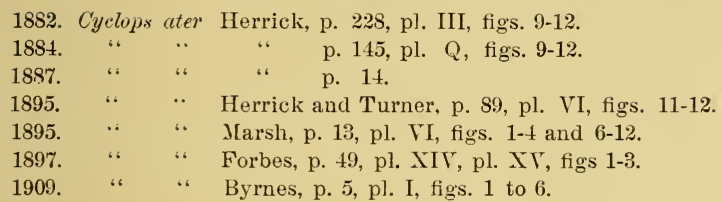

A large species, conspicuous both on account of its size and its brilliant colors. The cephalothorax is oval and very broad. The length and breadth of the first segment are about equal, and this segment comprises more than two-thirds the entire length of the cephalothorax. The cephalothorax is nearly three times the length of the abdomen, exclusire of the furcal rami.

The first abdominal segment is short and stout and very little enlarged at its anterior end. The succeeding segments are nearly equal in length, each being about one-third the length cf the first segment. The posterior margin of the last segment is armed with small spines.

The furcal rami are about twice as long as wide. Herrick has a figure in which the furcal rami are ciliated on the inner margin. I do not find the cilia in my specimens, and Forbes (Forbes '97) states that they are not ciliate. The lateral spine is situated near the end. Of the terminal setae, the outer is slightly shorter than the inner, the second is about twice as long as the outer, and the third about three times as long.

The first antennae are 17 -segmented and reach nearly the full length of the cephalothorax. The twelfth segment has a sensory club, and the sixteenth and seventeenth segments have a lateral hyaline lamella with an entire edge. This iamella, in the seventeenth segment projects as a blunt process beyond the end of the segment.

The spinous armature on the terminal segments of the 
exopodites of the swimming feet is represented by the formuia $3,4,4,3$.

The fifth foot is composed of one segment and is armed with a stout serrate spine and two long setae.

The form of the receptaculum seminis is shown in plate LXXII, fig. 5.

Average length of the female $1.77 \mathrm{~mm}$. This is the size of my specimens. Herrick gives $2.1 \mathrm{~mm}$. as the average length and Forbes $1.77 \mathrm{~mm}$. to $2.88 \mathrm{~mm}$.

The deep blue of the ordinary coloration is rery marked. This color is most pronounced in the appendages and caudal setae and in the posterior margins of the segments of the cephalothorax. Sometimes the cephalothorax is of a deep red or brown.

Herrick's description was written from specimens collected in Mud lake, Hennepin Co., Minn. He afterwards stated that it was found from Alabama to Minnesota, and more abundantly towards the south. Reighard collected it in Lake St. Clair. I have obtained it from Round lake, Twenty-sixth lake, Intermediate lake and Susan lake in Michigan, and from Rush lake, Catfish lake, and Lake Winnebago in Wisconsin. Forbes reports it from the shallow lakes near Havana, Ill. These are the only recorded localities. It appears to be a rather rare form.

\section{CYCLOPS VIRIDIS JURINE.}

Plate LXXII, figs. 7 and 8. Plate LXXIV, figs. 1 and 2. Plate LXXIX, figs. 6 and $\%$.

1820. Monoculus quadricornis var. viridis Jurine, p. 46, pl. III, fig. 1.

1851. Cyclops viridis Fischer, p. 412, pl. IX, figs. 1-11.

1857a. " "brevicornis Claus, p. 32 , pl. III, figs. 12-1\%.

1857b. “ gigas Claus, p. 207, pl. XI, figs. 1-5.

1863. “ “ brevicornis Claus, p. 99, pl. IV, fig. 11.

1863. “ gigas Claus, p. 100.

$1863 . \quad$ " brevicornis Lubbock, p. 200.

$1870 . \quad$ " " Heller, p. 71.

1870. “ Clausii Heller, p. 73, pl. I, figs. 1 and 2.

1872. " Clausii Fric, p. 220, fig. 13.

1872. “ gigas Fric, p. 220, fig. 14.

1875. “ viridis, Uljanin, p. 30, pl. VII, figs. 3-9.

1876a. “ brevicornis Hoek, p. 13, pl. I, figs. 5 and 6. 
1878. Cyclops gigas Brady, p. 105, pl, XX, figs. 1-16.

1880. " viridis Rehberg, p. 540.

1880. “ " gigas Rehberg, p. 541.

1882. " ingens Herrick, p. 228, pl. IV, figs. 1-8.

1882. “ parcus Herrick, p. 229, pl. VI, figs. 12-15.

1882. " " insectus Forbes, p. 649, pl. IX, fig 6 .

1883. “ " viridis Cragin, p. 3, pl. IV, figs. 8-16.

1883. “ " uniangulatus Cragin, p. 6, pl. IV, fig. $1 \%$

1884.

1884 .

1884 .

1884.

1884

1885 .

1886.

1888.

1890 .

1890.

1891.

1891.

1891.

1892 .

1893.

1893.

1893.

1895 .

1895 .

1895 .

1895 .

viridis Herrick, p. 145.

parcus Herrick, p. 148, pl. R, fig. 22.

orevispinosus Herrick, p. 148, pl. S, figs. 7-11.

uniangulatus Herrick, p. 149.

insectus Herrick, p. 152, pl. U, fig. 9.

viridis Daday, p. 214.

“ Tosseler, p. 196, pl. IV, figs. 11-14.

“ Sostaric, p. 64, pl. I, fig. 7.

“ Thallwitz, p. 79.

“ Lande, p. 44, pl. XIX, figs.117-124, pl. XX, fig. 125.

“ Schmeil, p. 29.

“ Richard, p. 226, pl. VI, fig. 4.

“ Brady, p. 17, pl. V, figs. 6-10.

“ Schmeil, p. 9\%, pl. VIII, figs. 12-14.

americanus Narsh, p. 202, pl. IV, figs. 8-10.

brexispinosus Marsh, p. 204, pl. IV, figs. 11 and 12. pareus Marsh, p. 208, pl. IV, fig. 16, pl. V, fig. 1 .

viridis Herrick and Turner, p. 90, pl. XIV.

americanus Herrick and Turner, p. 91, pl. XIV.

ingens Herrick and Turner, p. 92.

pareus Herrick and Turner, p. 93, pl. XX, figs. 12-15, pl.

XXI, fig. 22, pl. XXIII, fig. 8, pl.. XXXIV, figs. 1-8.

1895

brevispinosus Herrick and Turner, p. 95, pl. XXIII, figs.

1-4, pl. XXIV, figs. 7-12.

1895.

uniangulatus Herrick and Turner, p. 96.

1895 .

brevispinosus MIarsh, p. 14, pl. VII, fig. 12.

1895 .

parcus Narsh, p. 15.

1897.

viridis Forbes, p. 37, pl. X, figs. 1-3.

1897.

1897.

1897.

1897.

1898.

1898.

1901.

1901.

1903.

1903.

1903.

1905 .

1905 .

“ var. brevispinosus Forbes, p. 41, pl. XI, figs. 1 and 2.

“ var. insectus Forbes, p. 41, pl. XI, figs. 3-6.

“ Steuer, p. 6.

“ Matile, p. 128, pl. II, figs. 15 and 16.

“ Scourfield, p. 324.

americanus Brewer, p. 132.

gigas Lilljeborg, p. 5, pl. I, figs. 1-5.

viridis Lilljeborg, p. 8, pl. I, figs. 6-11.

“ Graeter, p. 523, pl. 15. fig. 6.

“ Scourfield, p. 534.

parcus Byrnes, p. 152.

“ Jensen, p. 118.

“ var. insectus Pearse, p. 150. 
1909. Cy .lop: americanus Byrnes, p. 13, pl. V, figs. 1-3.

1909 . " parcus Byrnes, p. 14, pl. VI, figs. 1-8, pl, X, figs. 1-3.

1909. “ “ brevispinosus Byrnes, p. 16, pl. VII, figs. 1-9.

1909. “ ingens Byrnes, p. 22, pl. VIII, figs. 1-4.

Cephalothorax oval, its breadth rather more than onehalf its length. The cephalothorax is about twice as long as the abdomen exclusive of the furcal rami. Each cephalothoracic segment projects beyond the one following it.

The anterior part of the first abdominal segment is larger than the posterior, but this difference is not so marked as in some other species. The posterior margins of all the abdominal segments except the last are serrate,- - the last segment is armed with small spines; this armature of the abdominal segments is more marked in the immature forms.

The furcal rami are very variable in length. They may be scarcely longer than the last abdominal segment or they may be four times as long. In some varieties the rami are ciliate on the inner margins. The lateral seta of the furca is commonly well towards the distal end, varying in position from two-thirds to four-fifths the length of the ramus. Of the terminal armature of the furca, the outermost is very variable; it may be a slender plumose seta, or it may be a short, blunt spine. It is never, however, very much elongated.

The first antennae are 17-segmented and reach to or a little beyond the posterior margin of the first cephalothoracic segment. The twelfth segment has a club-shaped sense hair.

The spinous armament of the terminal segments of the exopodites of the swimming feet may be $2,3,3,3$, or $3,4,4,4$. The terminal segment of the endopodite of the fourth foot may have exteriorly either a seta or a spine.

The fifth foot, Plate LXXII, figs. 7 and 8 consists of two seg: ments. The first segment is broad, its breadth ordinarily equalling or exceeding its length; on its inner distal segment it bears a long plumose seta. The second segment is of about the same length as the first segment, while its width is onehalf or less than that of the first segment: on its distal end near the outer margin is a long plumose seta, at the inner 
angle on the distal end is a small, lanceolate spine; in some varieties this spine is separated from the segment by a joint, while in others, this joint does not appear.

The form of the receptaculum seminis is shown in the figure, Plate LXXIV, fig. 2.

It varies greatly in size. The common American varieties are 1.25 to 1.5 in length. It may reach, however, as much as $5 \mathrm{~mm}$.

Cyclops viridis seems to be universally distributed in the northern hemisphere.

\section{Cyclops viridis var. ingens, Herrick.}

This variety, which is also mentioned by E. B. Forbes, is distinguished by three features, first its greater size, second by the fact that the spine of the second segment of the fifth foot is not separated from the segment by a joint, and third by the ciliated internal margins of the furca. It corresponds, doubtless to the gigas of Claus. Inasmuch, however, as so good an authority as Schmeil considers that gigas differs from typical viridis only in size, it seems to me wise to retain Herrick's name for the American variety.

Ingens occurs in pools.

\section{Cyclops viridis var. brevispinosus Herrick.}

Brevispinosus is rather elongate in form, the furcal rami are long and slender, and the terminal appendage at the outer angles of the furcal rami is a short thick spine, Plate LXXIX, fig. 7, shaped much like the blade of a knife. The formula for the spines of the terminal segments of the exopodites of the swimming feet is $3,4,4,4$. The terminal segment of the endopodite of the fourth foot has a spine on its outer margin.

Brevispinosus is most common in larger bodies of water where it frequently has a limnetic habitat. It is by no means confined to large bodies of water, however, as it is found in many of the smaller lakes of Wisconsin and Michigan. 
Cyclops viridis var. parcus Herrick.

Parcus has the second segment of the fifth foot with the spine separated by a joint. The formula for the spines of the terminal segments of the exopodites of the swimming feet is $2,3,3,3$, the terminal segment of the endopodite of the fourth foot is armed with a seta. The outer terminal appendage of the furca is a short seta.

Parcus is most common in shallow bodies of water. It does not appear to have a very wide distribution.

\section{Cyclops viridis var. americanus Marsh.}

Americanus has the furcal rami of varying length, the outer terminal appendage a short seta. (Plate LXXIX, fig. 6.)

The spine of the second segment of the fifth foot is separated by a joint. The terminal segments of the exopodites of the swimming feet have as the formula of the spines $3,4,4,4$. The terminal segment of the endopodite of the fourth foot has externally a seta.

Americanus is the most abundant variety of viridis in American waters, being found almost universally especially in the smaller bodies of water. This is the form which E. B. Forbes calls insectus, reviving the name proposed by S. A. Forbes, but never so described as to make it possible to identify the form. It is evident that in this case americanus has the rights of priority, as it was possible to recognize insectus only after the publication by E. B. Forbes in 1897, and he recognizes the identity of the two forms.

\section{Discussion of viridis.}

The first to recognize clearly the identity of the forms which are here grouped under the common specific name of viridis was E. B. Forbes, and the synonomy which I have adopted does not differ materially from that proposed by him. I agree with him that all the varieties distinguished above merge the one into the other with no clear cut dividing line. This is my impression from the study of my somewhat extensive collections from nearly all sections of North America. 
The work of Miss Lehmann (Lehmann '03) proved this in regard to the distinctions between brevispinosus and americanus. And yet I am inclined to put much more stress than does Forbes on the varietal distinctions. While we can find connecting forms, if we look for them, yet it is true that collections from any locality are apt to contain only one variety. in abundance. It is true that one can find the blunt furcal spine of brevispinosus merging by insensible stages into a seta, but it is also true that we can make collections in which practically all the individuals have the blunt spine. These same individuals will have, correlated with the blunt spine, elongated furcal rami, a formula for the spines of the terminal segments of the exopodites of the swimming feet represented by $3,4,4,4$, and a spine on the external margin of the terminal segment of the endopodite of the fourth swimming feet. One may find brevispinosus forms with a seta on the external margin of the terminal segment of the endopodite of the fourth swimming foot, but this is by no means common. So when one finds parcus forms he is not likely to find other forms mingled with it. So with the americanus. There are grades connecting this with the other varieties, but in any given collection where americanus is found, nearly all will be typical americanus.

It is true that the armature of the swimming feet may rary, but variation is not so common, in my experience, as would be inferred from the statements of Forbes. I have even found a form in which the right and left fourth feet in the same individual had a different spinous armature, but this is so unusual, that it may be considered, in all probability, as the result of some mutilation.

I have sometimes thought that we might well consider these varieties as distinct species, and that the intermediate forms were the result of hybridizing. Whether this is true or not could only be determined by a course of breeding, and it is likely to be a long time before we shall know the pedigrees of the species of Cyclops. Meantime students who must discuss these forms as elements in the plankton, and who, perhaps, have no interest in the taxonomic side of the question, must 
have some means of designating the forms, and it makes little difference to them whether they are called species or varieties. This is my excuse for proposing the use of these varietal names.

The European type of viridis does not have the spine of the second segment of the fifth foot separated by a joint, has for the spine formula of the terminal segment of the exopodite of the swimming feet $2,3,3,3$, and has the internal margin of the furcal rami ciliate. There are, among the European forms, however, all the variations noted in the American forms. The typical form is vastly the more common in Europe, while in America americanus is the most widely distributed variety, ingens and parcus being comparatively rare.

\section{CYCLOPS BICUSPIDATUS ClaUs.}

Plate LXXIII, figs. 1-11; Plate LXXIX, fig. 11.

1857a. Cyclops bicuspidatus Claus, p. 209, pl. XI, figs. 6 and 7.

1863. " " " " , 101.

1863. “ " " pulchellus Sars, p. 246.

1870. “ " bicuspidatus Heller, p. 71 .

1872. “" " " Fric, p. 221, fig. 16.

1875. “ odessanus Schmankewitsch.

1876a. “ bicuspidatus Hoek, p. 17, pl. I, figs. 7-11.

1880. “ " pulchellus Rehberg, p. 543.

1850a. “ helgolandicus Rehberg, p. 64, pl. IV, fig. 5.

1882. “ " " pulchellus Vejdowsky, p. 63, pl. VII, figs. 11 and 12.

1882. “ "Thomasi Forbes, p. 619, pl. IX, figs. 10, 11 and 16.

1882. “ navus Herrick, p. 229, pl. V, figs. 6-13, 15-17.

1883. “ gigas G. M. Thompson, p. 96, pl. IX, figs. 8-10.

1883. “ pectinatus Herrick, p. 499. pl. VII, figs. 25 and 28.

1883. “ "Thomasi Cragin, p. 3, pl. III, figs. 1-13.

1884. “ " " Herrick, p. 151, pl. U, figs. 4, 5, 7 and 8 .

1884. “ " navus Herrick, p. 152.

1885. “ “ pulchellus Daday, p. 220.

1885. “ “ Entzii Daday, p. 221, pl. I, figs. 1-6.

1886. “ “ pulchellus Vosseler, p. 194, pl. V, figs. 19-29.

1888. “ “ " “ $\quad$ Sostaric, p. 66, pl. I, figs. 8 and 9.

1890. “ “ “ $\quad$ “ Lande, p. 50, pl. XXI, figs. 146-155.

1890. “ “ “ " " " "

1891. “ "Thomasi Forbes, p. 70\%, pl. II, fig. 8.

1891. “ “ " Brady, p. 14, pl. VI, figs, 1-4.

1891. “ bicuspidatus Schmeil, p. $2 \%$.

1891. " “ "

1892. “ “ Schmeil, p. 75 , pl. II, figs. 1-3. 


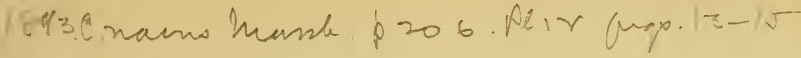

Marsh-North American Species of Cyclops.

1892. Cyclops pulchellus Lande, p. 161.

1893. " " Marsh, p. 20\%, pl. IT, figs. 18 and 19.

1893. " " minnilus Forbes, p. 247.

1893. " " serratus Forbes, p. 247.

1895. “ pulchellus Herrick and Turner, p. 101, pl. XXVII, figs. 4 and 5, pl. XXVIII, figs. 5-8.

1895. " " pulchellus var. navus Herrick and Turner, p. 102.

1895. “ minnilus Herrick and Turner, p. 103.

1895. " " Forbesi Herrick and Turner, p. 104.

1895. “ pulchellus Marsh, p. 15, pl. VII, fig. 14.

1897. " " bicuspidatus Forbes E. B., p. 44, pl. XII, figs. 1-4.

1897. “ " bicuspidatus Steuer, p. 5, pl. III, fig. 1.

1898. " " pulchellus Brewer, p. 133.

1898. " " navus Brewer, p. 132.

1901. “ bicuspidatus Lilljeborg, p. 11, pl. I, figs. 12-17, pl. II, fig. 1.

1903. “ " " Graeter, p. 528, pl. XT, figs. 23 and 32.

1909. “ bicuspidatus Byrnes, p. 25, pl. X, figs. 4-7.

The cephalothorax is elongate oval, its length being considerably more than twice its breadth. Seen from above the lateral angles of the segments back of the first are somewhat extended backward. The cephalothorax is rather more than twice as long as the abdomen exclusive of the furcal rami.

The first abdominal segment is only slightly narrower than the last cephalothoracic segment, and its anterior part is considerably wider than the posterior. The first abdominal segment about equals in length the three following. The posterior margins of the abdominal segments are more or less clearly marked with serrations, with the exception of the last seg. ment which is armed with small spines.

The furcal rami (Pl. LXXIII, figs. 3, 7 and 8, pl. LXXIX, fig. 11) vary greatly in their length. The length may exceed little more than twice the breadth, or it may reach to six or eight times the breadth. The inner margins of the rami are ordinarily ciliate, although this is not an invariable characteristic. At about one-quarter of the distance from the proximal end is a row of small spines on the lateral margin. These spines are almost invariably present on the forms with elongated furcal rami but are not found on those with the very short rami. The lateral seta, which is surrounded with minute spines, is placed at about two-thirds of the length of the ramus. Of the terminal setae, only the inner ones are elongated. 
The antennae consist of 17 segments. Richard (Richard 1891) and Steuer (Steuer '97) have shown that the number of antennal segments varies in the European forms, but I have not found this to be true in my American collections. The antennae vary somewhat in length, reaching about to the end of the first cephalothoracic segment, but they may fall short of this. length or exceed it. The twelfth segment bears a sensory club. The setae arming the segments are rather short.

The spinous armature of the terminal segments of the swimming feet is $2,3,3,3$.

The fifth foot (Pl. LXXIII, figs. 10 and 11) consists of two. segments. The breadth and length of the first segment are about equal; it bears on its outer distal angle an elongate plumose seta. The second segment is commonly twice as long as broad, but it may be still more slender; on its outer distal angle it bears an elongate and plumose seta, on its inner distal angle it bears a spine like seta which is less than half the length of the outer seta. This inner seta may be serrate as in the European forms, but neither the serration of this seta nor the plumose character of the other setae is very commonly seen in our American forms. The outer seta is borne upon a process of the segment, the outer margin of the segment being longer than the inner.

The size is somewhat variable, the American forms, apparently, being smaller than those found in Europe. The fomale is commonly about $1.1 \mathrm{~mm}$. in length but may be not more than $.95 \mathrm{~mm}$.

C. bicuspidatus is found in all our northern states north of the Ohio river, and has been collected as far north as the Saskatchewan.

Generally speaking those found as limnetic forms have an elongated form, while those in shallow bodies of water and pools are shorter. Herrick's navus (Pl. LXXIX, fig. 11) is an example of this short form. There is no doubt that navus is simply a variety of bicuspidatus for I can verify the statoment of Forbes that all intermediate forms can be found. Bicuspidatus is the common limnetic form of the Great Lakes, and in its elongated form is common in other deep lakes, 
although it is not confined to them. I have already discussed (Marsh 1903) its occurrence in Wisconsin lakes. It seems to prefer cold water, and my work in Wisconsin seemed to show, that it might be considered as preeminently a winter form.

Miss Pratt (Pratt 1898) finds it a winter form in Lake Bassenthwaite in England. I have found it in small bodies of water in Indiana in the winter, while in the cold lakes of the Rocky Mountains it is a summer form.

Birge and Juday, in a recent paper (Birge and Juday 1908) have noted an interesting fact in the life history of $C$. bicuspidatus. In certain of the Wisconsin Lakes, in the summer season it is found in large numbers in a resting stage enclosed in a cocoon, hatching out in the fall. The authors find themselves unable to correlate this cocoon stage with either changes of temperature or oxygen content of the water. It would seem to us from our knowledge of the habits of the species, that it is probable that temperature will be found to be the controlling cause of this encystation.

\section{CYCLOPS LEUCKARTI CLAUS.}

Plate LXXIV, figs. 4-11; Plate LXXV, figs. 1-3.

1857. Cyclops Leuckarti Claus, p. 35, pl. I, fig. 4, pl. II, figs. 13 and 14 .

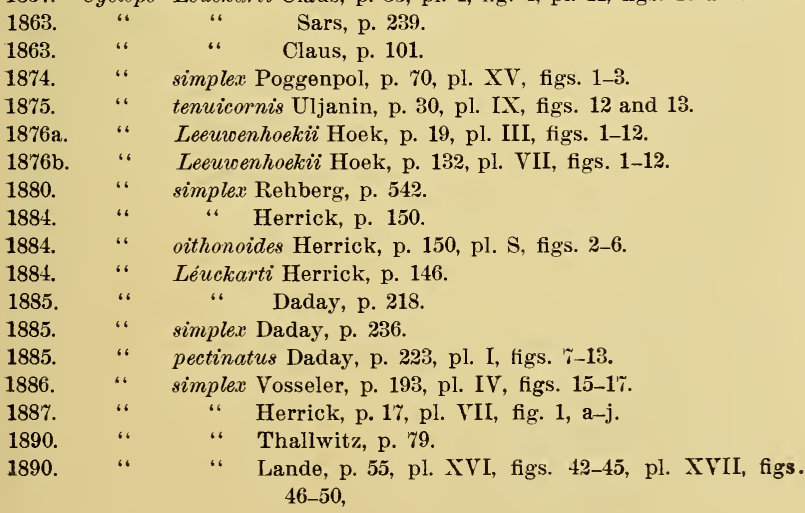


1891.

1891.

1891.

1891.

1892.

1892.

1893.

1895.

189

1897.

1897.

1897 ,

1897.

1898.

1900.

1901.

1903.

1905.

1909.

Cyclops Leuckarti Schmeil, p. 25.

“ $\quad$ Richard, p. 230, pl. VI, fig. 20.

edax Forbes, p. 709 , pl. III, fig. 15, pl. IV. figs. 1-20.

Scourfeldi Brady, p. 10, pl. IV, figs. 1-8.

Leuckarti Schmeil, p. 57, pl. III, figs. 1-8.

simplex Lande, p. 161.

“ Leuckarti Marsh, p. 209, pl. IV, fig. 1\%, pl. V. figs. 2-6.

“ Leuckarti Herrick and Turner, p. 96, pl. XVI, figs. 1-11, pl.

XVIII, fig. 1, a-j, pl. XXIV, figs. 2-6.

Leuckarti Marsh, p. 15, pl. VII, fig. 15.

“ Leuckarti Forbes, p. 31, pl. VIII, figs. 1-3.

“ edax Forbes, p. 33, pl. IX, fig. 1-3.

“ Leucliarti Scott, p. 322, pl. IX, figs. 23-25.

" "

" " Brewer, p. 131.

" ‘ Burckhardt, p. 640 .

" " Lilljeborg, p. 35, pl. II, tigs, 28-29.

" " Graeter, p. 509, pl. 15, figs. 26 and 30.

. Van Douwe, p. 681.

pulchellus Byrnes, p. 2t, pl. X, figs. 1-3.

A conspicuously slender species. The length of the cephalothorax compares with that of the abdomen as 7 to 4 . The breadth of the cephalothorax is about one-half its length. The elongated oval form of the cephalothorax is a characteristic peculiarity of this species. The segments of the cephalothorax do not project markedly on the sides.

The abdomen (Pl. LXXIV, fig. 3) is slender. The first segment is equal in length to the remaining segments, and its anterior end is only slightly larger than the posterior. The succeeding segments are all of about the same length. The last segment is armed posteriorly with a row of spines.

The furcal rami equal in length the two preceding segments. Generally the inner margins are ciliated, although this is not always the case. The lateral seta is so situated as to divide the furca in the ratio of three to two. The terminal setae vary in their length; of the four, the inner is more than twice as long as the outer, the outer is commonly not far from the length of the furca.

The first antennae are 17 -segmented and reach to the fourth cephalothoracic segment. The twelfth segment bears a sensory club. Upon the sixteenth and seventeenth segments is a 
lateral hyaline lamella. The lamella on the seventeenth segment is serrate on its margin, and has besides either a single deep depression near its distal end, or four or five such depressions. The figure (Pl. LXXIT, fig. 10) shows a common form. I do not find, in our American forms the spines spoken of by Schmeil on the antennal segments.

The segments of the second antenna (Pl. LXXV, fig. 3) are elongated. The lower margin of the second segment of the outer maxillipede always has a number of shallow depressions, giving it a more or less crenulated appearance. This appearance is described by the German authors under the term ge.perlte. While, in some of our forms, this term could be properly applied, more frequently crenulated would describe the appearance more accurately. The figures (Pl. LXXIV, figs. 4, $5,6)$ show the extreme forms as they occur in America. In one (Pl. LXXIV, fig. 4) this appearance is confined to only a small part of the margin, but is there very distinct, while in the other (Pl. LXXIV, fig. 6) it is not so marked but extends through the greater part of the length of the margin. Pl. LXXIV, fig. 5 shows another form intermediate between the others.

The second segment of the inner maxillipede has on its anterior margin a number of scattered and rather long setae (Pl. LXXIV, fig. 11). This seems to be a constant characteristic of this species; I think it was first mentioned by Brady (Brady 1891) in his description of Scourfeldi. It is not mentioned by Schmeil but it is shown in his figure of the inner maxillipede.

The spinous armature of the terminal segments of the exopodites of the swimming feet is represented by the formula, $2,3,3,3$. The membrane connecting the feet of the fourth pair is armed on the posterior border with two blunt spines. (Pl. LXXV, fig. 1.) Each segment of the rami is armed on the distal border with a row of spines.

The fifth feet (Pl. LXXIV, figs. 8, 9) are two-segmented. The first segment is short and broad and bears upon its distal outer angle a plumose seta; this seta is ordinarily long as in Pl. LXXIV, fig. 9, but sometimes it is quite short, as in Pl. LXXIV, fig. 8. The second segment bears a long plumose seta 
on its distal end, and an almost equally long one on its inner side. This appendage of the inner side is spoken of by Schmeil as a spine, but in most of our specimens it would more properly be called a seta. There is a good deal of variability in the form and proportions of the fifth feet as shown in the figures of the plate.

The egg sacs are carried at a marked angle from the abdomen.

The form of the receptaculum seminis is shown in $\mathrm{Pl}$. LXXIV, fig. 7. Average length of females is about $1.14 \mathrm{~mm}$.

This is a truly cosmopolitan species, being found in nearly all parts of the world. In India it is reported as found not only in fresh water but in brackish ponds. (Annandale 1907.)

The synonomy of this species prior to 1891 has been discussed by Schmeil and there is no reason to dissent from his conclusions.

As pointed out by me in an earlier publication (Marsh '92) it appeared from Forbes's original description of edax, that the only reason for separating it from Leuckarti was the absence of hyaline membranes on the 16th and 17th antennal segments. E. B. Forbes (Forbes '97) redescribes the species. $\mathrm{He}$ states that the hyaline membranes are present on the 16 th and 17 th segments.

$\mathrm{He}$ makes the following points of difference between edax and Leuckarti:

1st. The hyaline membrane of edax has several deep indentations, Leuckarti but one.

2 nd. In $e d a x$ the 16 th and 17 th antennal segments are equal, in Leuckarti the 16th is a fourth longer.

3rd. The crenulations of the second segment of the outer maxillipedes are less marked.

4th. The abdominal stylets are more divergent in edax.

5th. In edax the surfaces of attachment of the setae of the terminal segment are parallel, in Leuckarti the surface of attachment of the proximal seta is at an angle of about fortyfive degrees with the long axis of the segment, instead of at right angles. In edax the distal segment is broader.

6th. Other differences which can only be recognized by a 
long series of measurements, but such "that one well acquainted with these species can distinguish them at a glance."

In regard to these points of difference, I can only say that none of them seem to me of more than varietal value. In regard to the indentations in the hyaline membrane of the last antennal segment, I find both forms in the same collection with every reason to think that they grade the one into the other. I have found, in my collections, the form with a single indentation the more abundant.

Burckhardt (Burckhardt 1900, p. 640) recognizing this possibility of variation, states that in his specimens, the outer three-fourths of the membrane was uniformly indented.

I have already discussed the variations in the crenulations of the second segment of the outer maxillipede. There is great variation in this characteristic.

The other points of difference are minor things, differences which one would expect within species limits. The sixth point of difference, of course, can hardly be taken seriously, for differences which can not be accurately defined should not be used in the diagnosis of a species. Without doubt, if we are to recognize the differences on which E. B. Forbes distinguishes edax we should have to use the name of Leeuwenhoekii Hoek, which has prior standing.

The figures in Brady's plate (Brady '91) make it evident that Scourfeldi is the same as Leuckarti.

It seems probable that pulchellus of Miss Byrnes (Byrnes 1909) is Leuckarti.

Cyclops Tenuis sp. nov.

Plate LXXV, figs. 4-9; Plate LXXIX, fig. 5.

A long slender species. The cephalothorax is oval, its length being more than twice its breadth; it is twice as long as the abdomen exclusive of the furcal rami. The segments of the cephalothorax do not project at their posterior angles.

The anterior end of the first abdominal segment (Pl. LXXV, fig. 5) is somewhat larger than the posterior end; this segment is less in length than the three following.

$$
\text { 7-S. \& A. - } 3
$$


The furcal rami are rather slender, nearly equalling in length the last two abdominal segments. The lateral seta is at about one-half the length of the ramus. Of the terminal setae, the outer is short, while the inner one is rather unusually long.

The first antennae (Pl. LXXV, fig. 7) are long, exceeding the second cephalothorax segment. The antenna is composed of seventeen segments, the twelfth bearing a sensory club. The terminal segments of the antenna have no special armature.

The spinous armature of the terminal segments of the exopodites of the swimming feet is $2,3,3,3$.

The fifth foot consists of two segments. The length of the first segment is rather less than twice its breadth; it bears on the outer distal angle a long seta. The second segment is twice as long as broad; on its outer distal angle it bears a seta; on its inner distal angle, but set back a little from the end, it bears a slender serrate spine or seta; this inner spine nearly equals in length the outer seta.

The form of the receptaculum seminis is shown in the figure (Pl. LXXV, fig. 9).

The females are about $1.1 \mathrm{~mm}$. in length.

This was found in Calabasas, in southern Arizona.

C. tenuis resembles, in its form, C. Leuckarti, but differs in the form of the fifth feet, in the lack of armature on the antennal segments, and of crenulatons on the outer maxillipede, and in the form of the receptaculum seminis.

It seems to be most nearly related to the European oithonoides. I at first thought it should be a variety of that species. The difference in the form of the fifth foot, however, with the lack of antennal armature and the somewhat different receptaculum seminis have led me to consider it a new species. 


\section{CYCLOPS ALBIDUS JURINE.}

\section{Plate LXXVI, figs. 1-9.}

1820. Monoculus quadricornis albidus Jurine, pp. 44 and 47, pl. II, figs. 10 and 11 , pl. III, fig. 24 .

1841. Cyclops annulicornis Koch, H. 21, pl. VI.

1850. " quadricornis var. b Baird, p. 202, pl. XXIV, fig. 4.

1857. “ tenuicornis Claus, p. 31, pl. III, figs. 1-11.

185\%. “ pennatus Claus, p. 35, pl. III, figs. 12-1\%.

1863. “ tenuicornis Claus, p. 99, pl. I, fig. 3 , pl II, fig. 17, pl. IV, fig. 5.

$1863 . \quad$ " tenuicornis Sars, p. 242.

1863. " " annulicornis Sars, p. 243.

1863. “ tenuicornis Lubbock, p. 202.

1870. “ tenuicornis Heller, p. 71.

1872. " " tenuicornis Fric, p. 219, fig. 12.

1874. “ Clausii Poggenpol, p. 70, pl. XV, figs. 4-14.

1875. “ “ signatus Uljanin, p. 29, pl. IX, figs. $6-11$, pl. XI, fig. 8.

1876a. “ " tenuicornis Hoek, p. 12.

1876b. “ tenuicornis Hoek, p. 130.

1878. “ " tenuicornis Brady, p. 102, pl. XVIII, figs. 1-10.

1882. “ tenuicornis Herrick, p. 227, pl. VI, figs. 1-11 and 20, pl, V, fig. 14.

1883. “ tenuicornis Cragin, p. 3, pl. II, fig's. 1-14.

1883. “ signatus var. fasciacornis Cragin, p. 2, pl. II, fig. 15.

1884. “ “ tenuicornis var. a Herrick, p. 153, pl. Q4, figs. 1-7.

1885. “ tenuicornis Daday, p. 211.

1886. “ “ tenuicornis Vosseler, p. 189, pl. IV, figs. 6-10.

1887. “ " tenuicornis Claus, var. distinctus Richard, p. 162.

1888. " " tenuicornis Claus, var. annulicornis, Richard, p. 61.

1888. “ albidus Sostaric, pl. I, figs. 3, 4 and 12.

1890. “ " tenuicornis Thallwitz, p. 79.

1890. “ " tenuicornis Lande, p. 36, pl. XVI, figs. 22-32.

1891. “ " "gyrinus Forbes, p. 707, pl. II, fig. 9, pl. III, fig. 14.

1891. " " albidus Schmeil, p. 23.

1991. " " annulicornis and tenuicornis Richard, p. 224-226.

1892. “ albidus Schmeil, p. 128, pl. I, figs. 8-14b, pl. IV, fig. 15.

1892. " " tenuicornis Lande, p. 156.

1892. “ " gracilicornis Lande, p. 158.

1893. “ signatus Marsh, p. 211, pl. V, figs. 7-9.

1895. “ signatus var. tenuicornis Herrick and Turner, p. 106, pl. XV, figs. 5-7, pl. XX, figs. 1-7, pl. XXXIII, figs. 1 and 2.

1895.

1897. albidus Marsh, p. 17, pl. VI, figs. 8-10.

1897. “ Forbes, p. 47, pl. XIII.

1898.

1901.

1901.

$1903 . \quad$ “ Graeter, p. 481, pl. 15, fig. 8. tenuicornis Matile, p. 121, pl. II, figs. 4 and 5.

“ signatus Brewer, p. 129.

“ albidus Lilljeborg, p. 49, pl. III, figs. 21, 22.

“ distinctus Lilljeborg, p. 47, pl. III, figs. 16-20. 
1905. Cyclops albidus Pearse, p. 150, pl. XIV, figs. 11 and 13.

$1906 . \quad$ " distinctus Brady, p. 697.

1909. " " signatus var. annulicornis Byrnes, p. 10, p. IV, figs. 1-6.

1909. “ virido-signatus Byrnes, p. 23, pl. IX, figs. 1-8.

A rather large species. The eephalothorax is oval in form, but the tapering at the posterior end is not so pronounced as in some species. The length and breadth compare as about 5 to 3 . The cephalothorax is a little more than twice as long as the abdomen exclusive of the furcal rami. The projection of the posterior angles of the segments is not very marked. The dorsal surface of the fifth segment is more or less clearly marked with four rows of small spines.

The first abdominal segment (Pl. LXXVI, fig. 5) is not markedly larger at its anterior end; this first segment is somewhat longer than the sum of the three following. The last abdominal segment has a row of spines on its posterior margin.

The furcal rami are about twice as long as wide. The inner margins of the furcal rami are not usually armed with cilia; sometimes, however, they are present. I have found this condition in specimens collected in Michigan and in some collected in Colorado. The lateral seta is situated near the end of the furca. Of the four apical setae, the outer is very short, not much exceeding in length the ramus; the inner is about three times the length of the outer.

The first antennae are composed of seventeen segments, and reach about the full length of the eephalothorax. The last three segments (Pl. LXXVI, fig. 8) bear a hyaline plate, which in the last segment may be finely serrate on the margin. In occasional specimens this hyaline plate may be seen in some of the preceding segments, and in exceptional cases may be traced the whole length of the antenna, being represented in most of the segments by a row of small spines. Occasionally, too, the eighth, ninth, tenth, twelfth, thirteenth and fourteenth segments may have a row of spines on the posterior border as in $C$. fuscus. The twelfth segment has a long seta and a clubshaped sensory seta. The first two segments may have irregular rows of spines. In exceptional cases, there may be rows of spinules on the fourth, fifth, sixth and serenth segments. 
In the second antenna, the inner margins of the first two segments are usually setose. The third segment is short, but little exceeding the second in lengtl. (Pl. LXXVI, fig. 7.)

The spinous armature of the terminal segments of the exopodites of the swimming feet is $4,4,4,3$.

The distal seta on the inner margin of the endopodite of the fourth foot is rudimentary, being represented by a small spine; very rarely there is a short seta in this place; I have nerer found a seta of full length. (Pl. LXXVI, figs. 1, 3.)

The fifth foot is of two segments (Pl. LXXVI, fig. 6). The first segment is longer than wide. It has a patch of spines on the inner margin near the base, and a few spines about midway of its inner margin which may extend over part of the surface of the segment in a curved line. The distal margin is armed with small spines. On its distal outer angle is a long seta. The length of the second segment about equals the breadth of the first. It bears a long median seta and two stout serrate setae, one at each distal angle; the inner of these lateral setae is the longer.

The form of the receptaculum seminis is shown in the figure, (Pl. LXXVI, fig. 9).

The egg sacs of the female stand out from the abdomen almost at right angles.

The females measure upwards of $1.5 \mathrm{~mm}$.

Cyclops albidus is universally distributed in North Americs. It belongs to the litoral rather than to the limnetic fauna.

Under C. fuscus there is a brief discussion of the distinguishing points between these two species.

C. annulicornis Sars, C. tenuicarnis var. distinctus Richard, and C. gracillicornis Lande are doubtless identical, and the names have been given to separate a form supposed to be intermediate between albidius and fuscus. Brady (1906) and Lilljeborg (1901) make a distinct species using the name distinctus of Richard. Nothing has appeared in our American copepod fauna which seems to need a distinct species name, and I am inclined to agree with Schmeil that there is no good reason for separating this form from albidus. Accordingly $I$ have placed them in the synonomy. 
From the description it is impossible to establish the identity of virido-signatus of Miss Byrnes, but it would seem that this is probably a larval form of either albidus or fuscus with the chances in favor of albidus.

\section{CYCLOPS FUSCUS JURINE. \\ Plate LXXVII, figs. 1-7.}

1820. Monoculus quadricornis fuscus Jurine, p. 47, pl. II, fig. 2.

1841. Cyclops signatus Koch, H. 21, pl. VIII.

1850. " quadricornis var. c. Baird, p. 203, pl. XXIV, fig. 5.

1857. coronatus Claus, p. 29, pl. I, fig 5, pl. II, figs. 1-11.

1863. “ “ " " p. 97 , pl. II, fig. 16, pl. $X$, fig. 1.

1863. “ signatus Sars, p. 242.

1863.

1870 . " "

1872. “ “ “

1876a. “ “ " " Hoek, p. 12.

1876b. “ " " Hoek, p. 129.

1878. “ signatus Brady, p. 100, pl. XVII, figs. 4-12.

1882. “ tenuicornis Herrick, p. 22\%, pl. V, fig. 14, pl. VI, figs. 1-11, and 20.

1884. “ “ Herrick, p. 153, pl. R, fig. 16, pl. Q4, figs. 8-11, and 21.

1885. “ signatus Daday, p. 208.

1886. “ " Vosseler, p. 189, pl. IV, figs. 1-5.

1888. “ " fuscus Sostaric, p. 58.

1890. “ signatus Thallwitz, p. 79.

1890. “ “ “ Lande, p. 33, pl. XV, figs. 1-12.

1891. " fuscus Schmeil, p. 22.

1891. “ “ " Richard, p. 223, pl. VI, fig. 6.

1891. “ signatus Brady, p. 6, pl. II, fig. 5.

1892. “ fuscus Schmeil, p. 123, pl. I, figs. 1-7b, pl. IV, fig. 2.

1893. " signatus Marsh, fuscus included under this.

1895. “ signatus var. coronatus Herrick and Turner, p. 106, pl. XV, figs. 1-4.

1895. “ fuscus Marsh, p. 16, pl. VI, figs. 5, 7 and 11.

1897. “ coronatus Matile, p. 120, pl. II, figs, 1,2 and 3.

1901. “ fuscus Lilljeborg p. 44, pl. III, figs 12-15.

1903. " " " Graeter p. 473, pl. 15, fig. 3\%.

1905. “ “ $\quad$ “ Pearse, p. 150, pl. XIV, fig. 12.

1906. “ signatus var. coronatus Byrnes p. 193, pl. VI1, figs. 1-6, pl. VIII, figs. 1-3.

1909. " " " " Byrnes p. 9, pl. II, figs. 1-7, pl. III, figs 1-5.

The cephalothorax is oval, narrowing decidedly toward the posterior end. Its width is rather more than one-half its 
length and the cephalothorax compares in length with the abdomen as seven to four. The posterior angles of the segments of the cephalothorax are not especially prominent. The first segment is about three-fourths of the length of the whole cephalothorax.

The first abdominal segment (Pl. LXXVII, fig. 1) is only slightly enlarged at its proximal end. Its length is rather less than the combined length of the three following segments. The last segment is armed on its posterior border with small spines.

The furcal rami are twice as long as wide, and ciliated on their internal margins. The lateral seta is near the distal end. Of the four terminal setae both the outer and the inner are elongated. The inner is seldom more than twice the length of the outer. All the terminal setae are strongly plumose.

The first antennae are composed of seventeen segments, and reach to the end of the cephalothorax. The twelfth segment bears a sensory hair. The eighth, ninth, tenth, twelfth, thirteenth and fourteenth segments have rows of large spines on their posterior borders (Pl. LXXVII, fig. 3). The last three antennal segments bear a lateral hyaline plate (Pl. LXXVII, fig. 4). In the last segment this hyaline plate is deeply notched on the first two-thirds of the segment, having four especially deep notches. The latter third of the plate is finely serrate. As in albidus these hyaline plates in some cases extend back upon the preceding segments. I find, as does Schmeil, contrary to the statement of Tosseler, that the indentations in the mem. brane of the last segment do not disappear in mounted specimens, but remain permanently like other cuticular structures.

In the second antennae, the inner margins of the first three segments are setose. The second segment is short and the third very long as compared with the corresponding structures in albidus. (Pl. LXXVII, fig. 5.)

The spinous armature of the swimming feet is $4,4,4,3$. This is as $I$ have found it in all my American specimens. Schmeil gives it 3, 4, 4, 3. Vosseler gives it, however, as I have found it.

A structure not mentioned by any of the European authors 
is found on the third segment of the endopodite of the fourth foot. The larger of the two terminal spines is armed on its inner margin with long irregular teeth instead of the short spines as is customary. (Pl. LXXVII, fig. 2.)

This feature I have found constant in specimens from the northern states, but it is absent in most of those that $I$ have examined from the southern states.

The structure of the fifth foot is like that of albidus.

The form of the receptaculum seminis is shown in the figure, Plate LXXVII, fig. 6.

The egg sacs of the female hang close to the abdomen.

The female measures 3 to $4 \mathrm{~mm}$. in length, according to Schmeil. American specimens are smaller, being little over half of this length.

This species is found widely distributed in the northern continents, although nowhere very abundantly. In the U. S. Herrick found it in Minnesota. Later I reported it from Wisconsin and Michigan. E. B. Forbes adds localities in Illinois and Massachusetts. Pearse reported it from Nebraska. I have found it also in collections from Arkansas and Louisiana, and it is probable that it is universally distributed.

As will be seen from the literature of the subject, albidus and fuscus have been confused with each other until Schmeil made the clear distinction between the two species. By the difference in size, the darker color of fuscus, and the different habit of the egg-sacs the two are easily distinguished at a glance. In albidus the egg-sacs stand out from the abdomen, while in fuscus they cling close to it. In albidus there is a sensory club on the twelfth antennal segment, while in fuscus that segment bears a sensory hair. In albidus the hyaline plate of the last antennal segment is finely serrate; in fuscus it is deeply notched. In albidus the third segment of the second antenna is short; in fuscus this segment is long. In albi$d u s$ the distal seta on the inner margin of the third segment of the endopodite of the fourth foot is rudimentary. In fuscus this seta is of the usual size, and commonly the large terminal spine of this segment is armed with long irregular teeth on its outer margin. In albidus the inner margins of the furcal 
rami are usually without cilia; in fuscus they are thickly beset with cilia.

\section{CYCLOPS HODESTUS HERRICK.}

\section{Plate LXXVIII, Figs. 1-4.}

1883. Cyclops modestus Herrick, p. 500.
1884. “ “ “ “ p. 15t, pl. R, figs. 1-5.
188\%. “ “ “ " "
1893. “ “ “ Marsh, p. 213, pl. V, figs. 10-13.
1893. " capilliferus Forbes, p. 248, pl. XL, figs. 14-17, pl. XLI, fig. 18.
1895. “ modestus Herrick and Turner, p. 108, pl. XXI, figs. 1-5.
1895. “ capilliferus Herrick and Turner. p. 109, pl. VI, fig. 13, pl. XXVIII, figs. 1-4.
1909. “ modestus Byrnes, p. 26, pl. XI, figs. 4 and 5.

A rather stout species. Cephalothorax broadly oval, its breadth exceeding one-half its length. The eephalothorax is considerably more than twice as long as the adbomen exclusive of the furcal rami. The first segment comprises nearly twothirds of the length of the cephalothorax. The posterior lateral angles of the segments project very little.

The abdomen (Pl. LXXVIII, fig. 4) is very slender and tapers little posteriorly. The first segment equals in length the rest of the abdomen exclusive of the furcal rami; it is wider at the anterior end, and the lateral prominences are each armed with a minute spine. The second and third segments are about equal in length, while the fourth is shorter. The abdominal segments are ciliate on their posterior borders.

The furcal rami are rather slender. They are about two and one-half times as long as the last abdominal segment. The inner margins are ciliate. The lateral seta is situated at about one-half the length of the ramus, and the ramus is peculiarly excavated backward from the seta. Of the terminal setae, the outer is short and plumose, and the inner is rather long, being three times the length of the outer.

The antennae (Pl. LXXVIII, fig. 2) are sixteen segmented. Herrick states that he has seen individuals "of a similar form" with seventeen segments. They reach, in the female, to the 
middle or end of the second cephalothoracic segment. The setae of the antennal appendages are unusually long.

The spinous armature of the terminal segments of the exopodites of the swimming feet is $4,4,3,3$. This is an ununusual armature.

The fifth foot (Pl. LXXVIII, fig. 3) is three segmented. The first segment is short and without armature. The second segment is nearly square and bears a seta on its outer distal angle. The third segment is narrower, longer than wide and bears two apical setae. Frequently the outer of these setae is bent over the inner.

Length of the females 1.2 to $1.25 \mathrm{~mm}$.

This was first described by Herrick from Alabama, and he afterwards reported finding it in Minnesota. I found it in two localities in Wisconsin and Forbes reports it from Wyoming, and states that it is an uncommon species in the north central states. I have received specimens from R. A. Spaeth collected at Haverford, Pennyslvania, and from C. F. Baker collected at Auburn, Alabama.

\section{CYPLOPS SERRULATUS FISCHER.}

Plate LXXVIII., Figs. 5-9, Plate LXXIX, Figs. 4 and 8.

1851. Cyclops serrulatus Fischer, p. 423, pl. X, figs. 22, 23, 26-31.

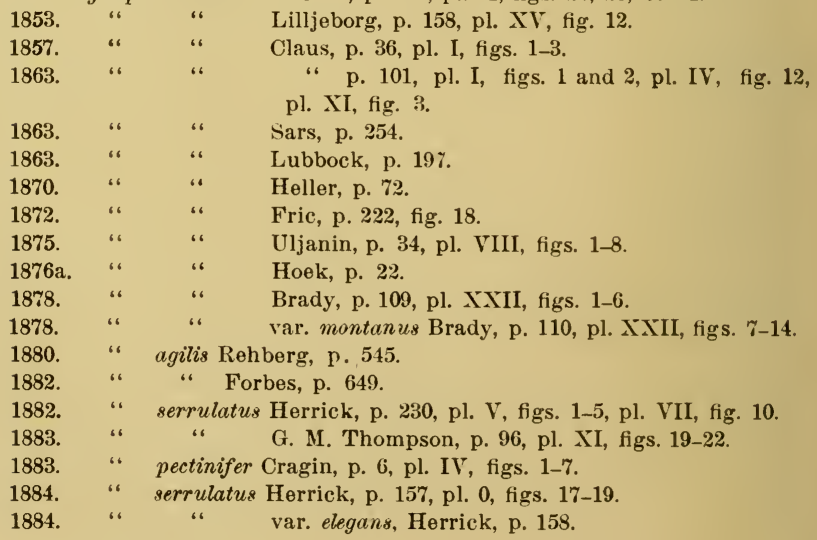


1885. Cyclops agilis Daday, p. 240.

1886. “ “ "

1890. " " " Thallwitz, p. 79.

1890 . “ " “ Lande, p. 60, pl. XVII, fig. 69, pl. XVIII, figs. 70-80.

1891. “ serrulatus Brady, p. 18, pl. VII, fig. 1.

1891. " agilis Forbes, p. 710.

1891. “ " serrulatus Richard, p. 234, pl. VI, fig. 19.

1891. " " " " Schmeil, p. 29.

1892. “ “ “ DeGuerne \& Richard, p. 11.

1892. “ " “ Schmeil, p. 141, pl. V, figs. 6-12.

1892. " agilis Lande, p. 164.

1893. “ serrulatus Marsh, p. 215, pl. VI, figs. 2-5.

1893.

" Richard, p. 8.

1893.

“ Scott, p. 73.

1895.

66

Herrick and Turner, p. 111, pl. XV, figs. 8-11, pl. XIX, figs. 2-5, pl. XXVI, fig. 10, pl. XXIX, figs. $17-19$.

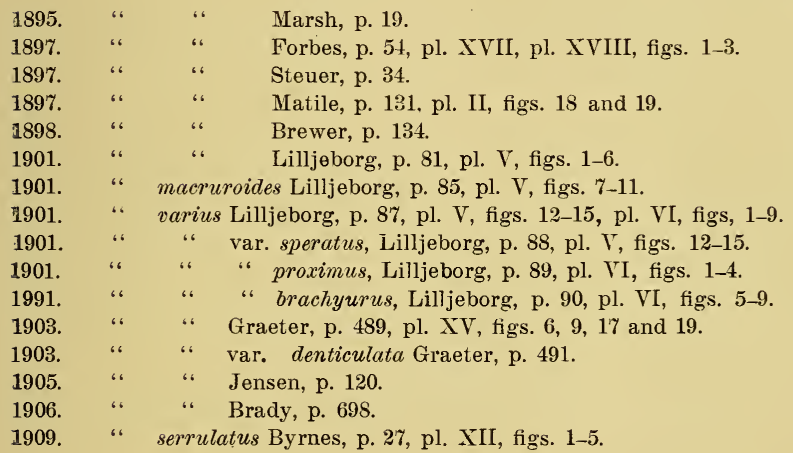

Cephalothorax (Pl. LXXIX, fig. 8) elliptical rather than oval, its breadth more than half its length. The segments do not noticeably project over the following ones. The cephalothorax is more than twice as long as the abdomen exclusive of the furcal segments.

The first abdominal segment is enlarged at the anterior end. The second, third and fourth segments are about equal in length. The last segment is bordered posteriorly by a row of spines, and the preceding segments are commonly dentate on their posterior borders.

The furcal rami vary greatly in length. At one extreme wo have the short stout form, perhaps one and a half times as long as 
the last abdominal segnent, and at the other extreme the slenderform in which the furca may be three times as long as the last abdominal segment. The form shown in the plate, (Pl. LXXVIII, fig. 7) may be considered typical while the figure in plate LXXVIII, fig. 6 is of the slender form. The outer margin of the furca is bordered by a row of short spines. These are not present in the male, and while always present in the female, are very variable in size. It was noted by DeGuerne and Richard ('92) that the specimens collected at Rufisque showed these spines much less clearly than did the European spec1. mens. Brady (Brady 1906) also states that the serrulations in the New Zealand specimens are less marked than in those in Europe. There is much variability even in the same general region. These short spines are commonly much more prominent at the distal end of the furca. The lateral seta is at the end of the furca. Of the terminal setae the outer is short, sometimes spine-like, and, in the specimens with a short furca, commonly stands at nearly right angles with the furca. The second and third setae are prolonged; the third is rather less than twice as long as the second and only slightly exceeds the combined length of the abdomen and furca. The fourth seta is slender and weak, seldom much exceeding the first in length, and sometimes is shorter.

The first antennae are twelve-segmented and reach to the third segment, or sometimes nearly to the fourth; their length is quite variable. The last three segments (Pl. LXXVIII, fig. 5) bear an inconspicuous hyaline membrane. Some of the European authors say that these hyaline memhranes are sometimes finely dentate, though commonly with entire margins. This dentation has never been noticed in American specimens.

The spinous armature of the terminal segment of the exopodites of the swimming feet is $3,4,4,3$.

The fifth foot (Pl. LXXVIII, fig. 8) is composed of a single segment. It is armed on its inner distal angle with a stout spine with serrate edges, and on its outer distal angle with a slender seta. Midway between these, on a prominent base is a long slender seta, considerable exceeding in length the outer seta. 
The form of the receptaculum seminis is shown in the figure, (Pl. LXXVIII, fig. 9).

The egg-sacs are elongate and stand out from the abdomen. 'The number of eggs is variable.

The size is variable, commonly running between .8 and 1.25 mm., but greater extremes are not unusual.

The species has been found so widely distributed that it may be considered cosmopolitan.

It is convenient to use the varietal names montanus Brady and elegans Herrick in speaking of the extreme forms. Montanus is small, dark colored with short and stout furca, and with few eggs in the egg sacs. Elegans is larger, slender, with long and slender furcae, and numerous eggs in the egg sacs. As indicated by me in a former publication (Marsh '92) montanus is more common in pools and elegans in lakes. Elegans may be considered as limnetic and montanus as litoral. There are exceptions to this distribution, however, for elegans may ke found in shallow waters, and in collections in the southern states it is not unusual to find both forms in the same collection.

\section{CYCLOPS PRASINUS FrSCHER. 2X \\ Plate LXXVIII, figs. 1, 2, 3 and 10.}

1860. Cyclops prasinus Fischer, p. 652, pl. XX, figs. 19-26a.

1871. " "longicornis Vernet, p. 44, fig. 3.

1882. " "fluviatilis Herrick, p. 231, pl. VIII, figs. 1-9.

1883. " " magnoctavus Cragin, p. 5, pl. II, figs. 14-23.

1884. " " fluviatilis Herrick, p. 159, pl. Q ${ }^{5}$, figs. 1-9.

1886. “ pentagonus Vosseler, p. 191, pl. V, figs. $32-37$, pl. VI, figs. 11 and 12 .

1887. “ " pentagonus var. vichyensis Richard, p. 162.

1887. " Aluviatilis Herrick, p. 15.

1888. “ " " prasinus Richard, p. 65.

1891. " " magnoctavus Brady, p. 19, figs. 1-4.

1891. " " pentagonus Schmeil, p. 31.

1891. " " " " Blanchard \& Richard, p. 515.

1891. " " " Richard, p. 233, pl. VI, fig. 8.

1892. “ " " " "

1893. " "fluviatilis Marsh, p. 214, pl. V, figs. 14 and 15, pl. VI, fig. 1.

1895. “ fluviatilis Marsh, p. 18.

1895. " fluviatilis Herrick and Turner, p. 114, pl. XXVI, figs. 1-8, pl. XXX, figs. 1. 
1897. Cyclops prasinus Forbes, p. 57, pl. XIX, figs. 1 and 2, pl. XX, figs. 1 and 2.

1898. “ "fluviatilis Brewer, p. 135.

1903. " " prasinus Graeter, p. 486, pl. 15, figs. 3 and 4.

1909. “ fluviatilis Byrnes, p. 28, pl. XV, figs. 1 and 2.

A small slender species. Its breadth exceeds one-half its length, and its length is rather more than twice the length of the abdomen exclusive of the furcal rami. The first segment is two-thirds the length of the entire cephalothorax. The last segment has a row of very fine hairs.

The first abdominal segment (Pl. LXXIX, fig. 1) is very slightly enlarged at its anterior end and the whole abdomen tapers gradually to the end of the furca.

The furca is short, being about one and a half times the length of the last abdominal segment. The lateral seta is situated at about the middle. Of the terminal setae the outer and inner are short and slender, the inner being the longer. The second and third are produced, the third being much the longer.

The first antennae (Pl. LXXIX, fig. 2) are composed of twelve segments and reach to the end of the third cephalothoracic segment. The last three segments bear a very minute hyaline membrane. The antennae are bent in a way that is peculiar to this species.

The spinous armature of the terminal segments of the exopodites of the swimming feet are $3,4,3,3$.

The fifth foot (Pl. LXXIX, fig. 10) is composed of one segment. It bears at the inner distal angle a slender spine, on the outer distal angle a seta, and between, on a conical base, an elongated seta.

The egg-sacs lie close to the abdomen.

The females average about $.48 \mathrm{~mm}$. in length. This is considerably smaller than the sizes given for the European specimens.

This species is widely distributed in Europe and has been reported from the Azores (Richard 1896), Ceylon (Daday '98) and Calcutta (Gurney 1906 and 1907). It is known to occur in America from the Rocky Mountains to the Atlantic and as far south as Mexico. Its characteristic habitat is lakes rather 
than pools. It is one of the common species in the limnetic regions of the Great Lakes.

\section{CYCLOPS PHALERATUS KOCH.}

Plate LXXIX, fig. 9; plate LXXX, figs 1-6.

1838. Cyclops phaleratus Koch, H 21, pl. IX.

\begin{tabular}{|c|c|c|}
\hline 1853. & “ & Lilljeborg, p. 208. \\
\hline $185 \%$. & “ & Claus, p. 37 , pl. I, figs. $6-10$. \\
\hline 1863. & “ & Claus, p. 102 , pl. IV, figs. $1-4$. \\
\hline 1863. & “ & Lubbock, p. 202. \\
\hline 1863. & “ & phaleratus Sars, p. 255. \\
\hline 1872. & “ & canthocarpoides Fric, p. 223, fig. 19. \\
\hline 1874. & “ & $\begin{array}{l}\text { lascivus Poggenpol, p. } 72, \text { pl. XV, figs. } 22-24, \text { pl. XVI, figs. } \\
7 \text { and } 8 .\end{array}$ \\
\hline 1874. & “" & $\begin{array}{l}\text { Fischeri Poggenpol, p. 73, pl. XV, fig. 28, pl. XVI, figs. } \\
12-15 \text {. }\end{array}$ \\
\hline 1875. & “ & phaleratus Uljanin, p. 38, pl. IX, figs. 1-5. \\
\hline 1878. & “ & Brady, p. 116, pl. XXIII, figs. 7-13. \\
\hline 1882. & “ & adolescens Herrick, p. 231, pl. VI, figs. 15-20. \\
\hline 1883. & “ & perarmatus Cragin, p. 7, pl. I, figs. 9-18. \\
\hline 1884. & “" & phalcratus Herrick, p. 161, pl. R, figs. 6-10. \\
\hline 1885. & “ & Daday, p. 252. \\
\hline 1887 & “ & Herrick, p. 14, pl. VII, figs. 2, a-d. \\
\hline 1888. & “ & Sostaric, p. 74, pl. II, figs. 21-22. \\
\hline 1890. & “" & Lande, p. 75 , pl. XX, figs. $126-136$. \\
\hline 1891. & “" & Brady, p. 25 , pl. IX, fig. 2. \\
\hline 1891. & “" & Richard, p. 238, pl. VI, fig. 12. \\
\hline 1891. & “ & Schmeil, p. 36. \\
\hline 1892. & " & Lande, p. 171. \\
\hline 1892. & “ & Schmeil, p. 170 , pl. VIII, figs. $1-11$. \\
\hline 1893. & “ & Marsh, p. 216, pl. VI, figs. 6 and 7. \\
\hline 1895. & “" & $\begin{array}{l}\text { Herrick, and Turner, p. } 120 \text {, pl. XVII, figs. 1-7, } \\
\text { pl. XVIII, figs. 2-2d, pl. XIX, fig. 1, pl. XXI, } \\
\text { figs. 6-10. }\end{array}$ \\
\hline 1895. & “ & Marsh, p. 19. \\
\hline 1897. & “" & Forbes, p. 59, pl. XX, fig. 3. \\
\hline 1901. & “" & Lilljeborg, p. 105, pl. VI. figs. 20-21. \\
\hline 1903. & “ & Graeter, p. 499. \\
\hline 1909. & “ & Byrnes, p. 31, pl. XV, figs. 1-9. \\
\hline
\end{tabular}

The cephalothorax (Pl. LXXX, fig. 1) is elliptical; its breadth is two thirds of its length. The first segment comprises nearly one-half of its length. The fifth segment is armed posteriorly with a row of spines. 
The abdomen is broad (Pl. LXXX, lig. 6), its first segment being only slightly smaller than the last cephalothoracic segment. Schmeil states that the second and third segments of the female and the second, third and fourth of the male are serrate on their posterior borders. I find some variations in these serrations in our forms.

The furcal rami are short, broad and tapering. They are armed upon their surfaces with rows of spines. The lateral setae are well towards the end, with spines at their bases. Of the terminal armature, the outer is a broad, stout spine, the inner a slender, short seta. The median setae are long and stout. The inner margins of the rami are ciliate.

The first antennae (Pl. LXXX, fig. 3) reach beyond the middle of the first cephalothoracic segment and, in American specimens are commonly composed of eleven segments. Herrick and Forbes claim to have collected mature specimens with ten segmented antennae. The eighth segment has a sensory hair.

The second antenna (Pl. LXXX, fig. 4) is short and broad. Besides the rows of small spines on the surface of the second segment, there is upon the anterior margin a row of curved tooth like spines. Near the end of the second segment is a stout spine, and a similar spine is located near the end of the third segment.

The spinous armature of the terminal segments of the exopodites of the swimming feet is $3,4,4,3$. The outer margins of the segments of the feet are armed with stout spines, and the first basal segment is armed posteriorly with a row of small spines.

The fifth feet (Pl. LXXIX, fig. 9) are widely separated from each other and each consists of a broad plate armed with three stout setae.

The form of the receptaculum seminis is shown in Plate LXXX, fig. 5 .

The egg-sacs lie rather close to the abdomen.

Length of female about $1.2 \mathrm{~mm}$. according to Schmeil, but American forms average somewhat smaller.

Cyclops phaleratus occurs in shallow lakes and stagnant 
pools, and is world wide in its distribution, although not abundant anywhere.

The question of the identity of our form with that of Europe has been discussed by Schmeil, and I think we must agree with his conclusion. Really the only reason for separating our form is the fact that it ordinarily has eleven segments in the antenna. If we recognize this as a specific difference we should call the American form perarmatus Cragin.

\section{CYCLOPS YARICANS SARS.}

1862. Cyclops varicans Sars, p. 252.

1875. " orientalis Uljanin, pp. $33-34$, pl. VII, figs. 10 and 11 ; pl. X, figs. 8-13; pl. XI, figs. 1 and 2.

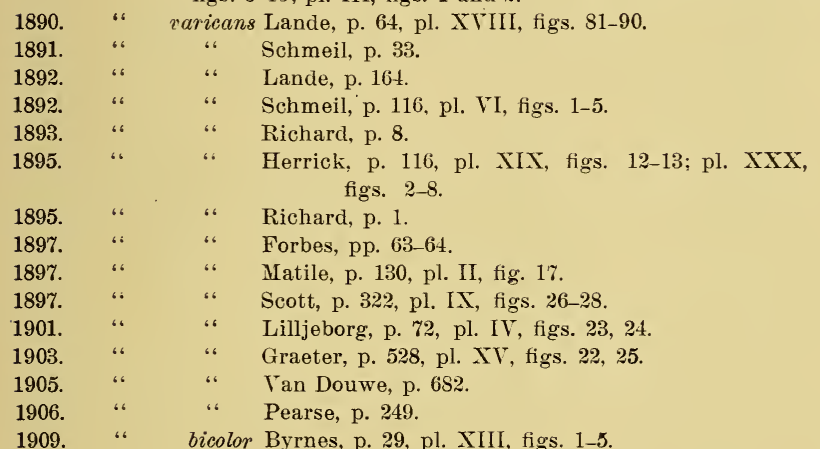

This is a species of world wide distribution, and it would be expected in our American fauna. I have never found it in any of the collections that have come under my observation. It is mentioned by Herrick, E. B. Forbes and Pearse as being found in America. Herrick states that he found it but once. His figures are not exact, but he gives twelve segments in the antenna of the female which should distinguish it from the closely related form bicolor. Forbes speaks of it as fairly common in America, but he gives neither description nor figures.

Pearse states that he found it on Nantucket Island, but he too, gives neither description nor figures. 
The bicolor of Miss Byrnes has antennae of twelre segments and must be considered as varicans.

Because of the very close resemblance of this species to bicolor one cannot help being a little skeptical in regard to some of these recorded occurrences, in spite of the fact that it might be expected to be a member of the American copepod fauna.

\section{CYCLOPS BICOLOR SARS.}

Plate LXXX, figs. 7-9; Plate LXXXI, figs. 1 and 2.

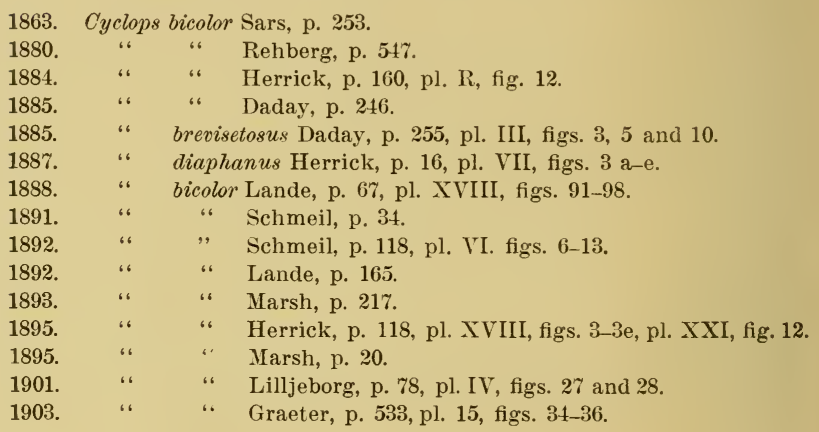

Cephalothorax oval, its breadth being slightly more than onehalf its length. The first segment comprises considerably more than one half of the cephalothorax. The cephalothorax is rather more than twice as long as the abdomen exclusive of the furcal rami. The fifth cephalothoracic segment bears upon each side a long seta.

The first abdominal segment (Plate LXXXI, fig. 1 ) is somewhat enlarged anteriorly and equals in length the remainder of the abdomen exclusive of the furcal rami. The last segment is armed with small spines on the ventral surface and is coarsely dentate on the dorsal surface.

The furcal rami do not equal the length of the last two abdominal segments. The lateral seta is at about threefourths 
of its length. The first and fourth of the terminal seta are short and slender, the inner exceeding the length of the outer.

The antennae (Plate LXXXI, fig. 2) have eleven segments, the third and seventh being the longer.

The swimming feet (Plate LXXX, figs. 7 and 8) are composed of two segments. The spinous armature of the terminal segments is $3,4,4,3$.

The fifth foot (Plate LXXX, fig. 9) consists of a single segment. It is slender and bears at the tip a single seta.

Average length of mature females .5mm.

Cyclops bicolor occurs in stagnant pools, and is widely distributed, although nowhere common.

I have notes of a mature female with antennae of ten segments. In this female the egg sacs contained only four or five eggs each while the more ordinary number is from fifteen to twenty.

This species, as described, does not correspond perfectly to the diagnosis of bicolor as given by Schmeil. There is a difference in the form of the fifth cephalothoracic segment and in the proportions of the furca.

There is, apparently some variation in the position of the fifth foot on the last eephalothoracic segment, and in some individuals, it resembles somewhat rubellus of Lilljeborg. The characters of the swimming feet, however, as given by Lilljeborg make a clear cut distinction between rubellus and bicolor. One might consider the American form a distinct species. The differences are slight, however, and besides are, for the most part, differences in structures which vary in other species, so that it seems to me better to consider our form as a variety of the European species. It may be added that because of its comparative rarity, a large number of individuals have not been studied, and a larger amount of material may show a closer relationship to the European form than now appears. 


\section{FIMBRIATUS FIscher.}

\section{Plate LXXXI, figs. 3-7.}

1853. Cyclops fimbriatus Fischer, p. 94, pl. III, figs. 19-28 and 30.

1863. " crassicornis Sars, p. 256.

1870. " Gredleri Heller, p. 74, pl. I, figs. 3 and 4.

1872. " pauper Fric, p. 223, fig. 20.

1875. “ crassicornis Uljanin, p. 39, pl. VIII, figs.9-16, pl. XII, fig. 1.

1878. “ crassicornis Brady, p. 118, pl. XXIII, figs. 1-6.

1880. “ $\quad$ Poppei Rehberg, p. 550, pl. 6, figs 9-11.

1880. “ " fimbriatus Rehberg, p. 548, pl. VI, figs. 7 and 8.

1882. " " Vejdowsky, p. 63, pl. VII, figs. 9. 10 and 13 .

1882. “ crassicornis Herrick, p. 232, pl. IV, figs. 9-14.

1884. " fimbriatus Herrick, p. 162, pl. R, fig. 1.1 .

1885. " " " Daday, p. 262 .

1885. “ margoi. Daday, p. 264, pl. III, figs. 20-25.

1886. “ fimbriatus Vosseler, p. 192. pl. VI, figs. 4-8.

1888. “ crassicornis Sostaric, p. 75, pl. II, figs. 23 and 24.

1890. “ fimbriatus Lande, p. 79, pl. XXI, figs. 166-169.

1891. “" " " Schmeil, p. 35.

1891. “ “ “ $\quad$ " Brady, p. 25, pl. IX, fig. 1 .

1891. “ " “ Richard, p. 238, pl. VII, figs. 13 and 14.

1892. “ " "

1892. " " " Lande, p. 173.

1893. “ " "

1895. " “ Herrick, p 121, pl. XVII, figs. 8 and 9, pl. XXI, fig. 11, pl. XXV, figs. 9-14.

\begin{tabular}{|c|c|c|c|}
\hline 1897. & “" & “ & Steuer, p. 7. \\
\hline 1901. & ، & “" & Lilljeborg, p. 94 , pl. VI, figs. $12-14$. \\
\hline 903. & “ & “ & Graeter, p. 503 , pl. 15 , fig. 1 . \\
\hline 1909. & ". & " & Byrnes, p. 33, pl. XV, figs. 3-7. \\
\hline
\end{tabular}

Cephalothorax (Plate LXXXI, fig. 3) oval, its breadth being a little more than two-thirds of its length. The cephalothorax is about one and seven tenths as long as the abdomen exclusive of the furcal rami. Each segment of the cephalothorax projects somewhat over the succeeding segment.

The last eephalothoracic segment is armed laterally with rather long hairs.

The anterior part of the first abdominal segment is somewhat larger than the posterior part. The last segments are armed posteriorly with spines.

The furcal rami (Pl. LXXXI, fig. 6) are commonly slender, slightly curred in outline, and with their outer extremities 
widely separated. Schmeil says that the length nearly equals the last three segments. In our forms this is rarely the case, the length being more generally equal to the last two and a half of the third, or about three times the length of the last segment. In some eases the rami are shorter yet, as in some specimens collected in the Saskatchewan. The lateral seta is situated at about two-thirds the length of the furca on the dorsal surface. A row of spines extends from the outer margin of the furca, on the dorsal surface opposite the seta, curving nearly to the center of the furca, and then nearly to the proximal end of the furca. Of the apical setae, the outer is spine like and short, the inner is slender and somewhat longer than the outer; the longest of the two middle ones nearly equals in length the cephalothorax.

The first antennae (Pl. LXXXI, fig. 2) of the female are composed of eight segments, are about two-thirds as long as the first cephalothoracic segment, and in repose lie nearly at right angles with the long axis of the animal. The fourth segment is the longest, and the fifth bears a sensory seta. The setae with which the antennal segments are armed, are, for the most part, long and stout. The segments near the base are quite stout, the first two being four times as wide as the terminal segment.

The external margins of the segments of the swimming feet (Pl. LXXXI, fig. 5) are armed with short, stout spines. The spinous armature of the terminal segments of the exopodites of the swimming feet is represented by the formula, 3, 4, 4, 3 .

The fifth foot (Pl. LXXXI, fig. 4) consists of a single segment, and is armed with one spine and two setae.

The egg-sacs, pl. LXXXI, fig. 3, lie alongside the abdomen, and contain only a small number of eggs.

The length of mature females varies from $.7 \mathrm{~mm}$. to $.84 \mathrm{~mm}$. This is somewhat smaller than the figures given by Schmeil for the European forms.

Cyclops fimbriatus is not a common species, but is cosmopolitan in its distribution.

The synonomy is giren before the description, and no ex- 
planations are required as it has been thoroughly discussed elsewhere.

\section{CYCLOPS AEQUOREUS Fischer.}

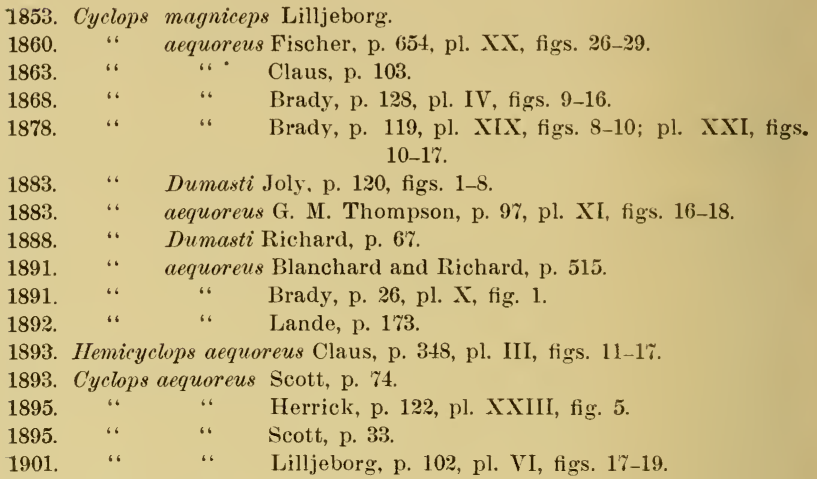

Cyclops aequoreus was first recognized in our fauna by Herrick. It is an inhabitant of brackish water. It has never appeared in any of my collections, but Mr. E. Foster tells me that he has collected it in Lake Ponchartrain and connecting waters. It seems likely that further collections in brackish waters will show that this is not an uncommon form. It is readily recognized by the six segmented antennae of the female and the peculiar form of the fifth foot. 


\section{BIBLIOGRAPHY.}

This bibliography includes only those papers of systematic importance in regard to the species treated of, and which have been quoted in this report.

Annandale, M.

1907. The fauna of brackish ponds at Port Canning, Lower Bengal. Part I. Records of Ind. Mus. Vol. I, Part I, pp. 35-43.

Baird, W.

1850. Natural history of the British Entomostraca. Ray Soc. Lond.

Birge, E. A. and Juday, C.

1908. A summer resting stage in the development of Cyclops bicuspidatus Claus. Trans. Wis. Acad. XVI, p. 1.

Blanchard, R. and Richard, J.

1891. Faune de lacs salés d'Algérie. Cladocères et Copépodes. Mem. Soc. Zool. France, T 4, No. 5 pp. 512-535.

Brady, G. S.

1878. Monograph of the free and semi-parasitic copepoda of the British Isles. 3 vols. Ray Soc. Lond.

1891. Revision of British species of fresh water Cyclopidae and Calanidae. Nat. Hist. Trans. Northumb. Durham \& Newcastle. XI, Part I, pp. $68-120$.

1906. On the entomostracan fauna of New Zealand Lakes. Proc. Zool. Soc. London pp. 692-701.

Brewer, A. D.

1898. A study of the Copepoda found in the vicinity of Lincoln, Neb. Jour. Cinn. Nat. Hist. Soc.

Vol. IX, pp. 119-138. 


\section{Wisconsin Academy of Sciences, Arts, and Letters.}

Burckhardt, G.

1900. Faunistsche und systematische Studien über das

Zooplankton der grösseren Seen der Schweiz und ihrer Grenzgebiete. Revue suisse de Zoologie, T 7 , pp. 353-713.

Byrnes, E. F.

1906. Two transitional stages in the development of $C y$ clops signatus var. coronatus. Biol. Bull. X, pp. 193-196.

1909. The fresh water Cyclops of Long Island. Cold Spring Harbor Monographs. VII. Pub. by Brooklyn Academy of Arts and Sciences.

Claus, C.

1857a. Das genus Cyclops und seine einheimischen Arten. Inaug. dis. Marburg.

1857b. Weitere Mittheilungen über die einheimischen Copepoden. Archiv. f. Naturgesch. Jahg. 23, Bd. 1, pp. 205-210.

1863. Die freilebenden Copepoden mit besonderer Berücksichtigung der Fauna Deutschlands der Nordsee und des Mittelmeeres-Leipzig.

1893. Neue Beobachtungen über die Organisation und Entwicklung von Cyclops. Ein Beitrag zur Systematik der Cyclopiden. Arb. aus dem Zoolog. Institute zu Wien, T $\mathrm{X}$, Heft 3, pp. 283356.

Cragin, F. W.

1883. A contribution to the history of the freshwater Copepoda. Trans. Kans. Acad. Sci. Vol. VIII. pp. 1-15.

Daday, E. von

1885. Monographia Eucopepodorum liberorum in Hungaria hucusque repertorum. A. M. tud. Akadémia altal a Vitéz-alaphól.

1898. Mikroscopische Süsswasserthiere aus Ceylon.

Budapest. 
Douwe, C. van.

1905. Copepoden von Transkaukasien, Transkaspien und Turkestan. Zoolog. Jahrb. Bd. 22, Heft 6.

Fischer, S.

1851. Beiträge zur Kenntniss der in der Umgegend von St. Petersburg sich findenden Cyclopiden. Bull. Soc. Imp. Moscou XXIV, pp. 409-438.

1853. Beiträge zur Kenntniss der in der Umgegend von St. Petersburg sich findenden Cyclopiden. Fortsetzung. Bull. Soc. Imp. Moscon. XXVI, pp. $74-100$.

Forbes, E. B.

1897. A contribution to a knowledge of N. A. freshwater Cyclopidae. Bull. Ill. State Lab. Nat. Hist. Vol. 5, Art. 2.

Forbes, S. A.

1882. On some entomostraca of Lake Michigan and adjacent waters. Am. Nat. XVI, pp. 537-542 and pp. 640-649.

1891. On some Lake Superior Entomoestraca. Rep. U. S. Fish Com. for 1887, pp. 701-718.

1893. A preliminary report on the aquatic invertebrate fauna of the Yellowstone Nat. Park. Wyo., and of the Flathead region of Montana. Bull. U. S. Fish Com. for 1891, Art. 6, pp. 207-258.

Fric, A.

1872. Die Krustenthiere Böhmens. Archiv. der Naturwiss. Landesdurchforsch. von Böhmen Bd. II, Abth. IV pp. 201-269.

Graeter, A.

1903. Die Copepoden der Umgebung Basels. Rev. Suisse Zool. T. 11, pp. 419-541.

Guerne, J. de, and Richard, J.

1892. Cladocères et copépodes d'eau douce de Rufisque.

Mem. Soc. Zool. de France, 526-538. 
Gurney, R.

1906. On some freshwater entomostraca in the collection of the Indian Museum, Calcutta. Jour. and Proc. Asiatic Soc. of Bengal, Vol. II, N. S. pp. 273-281.

1907. Further notes on Indian fresh water entomostraca. Rec. Indian Mus. Vol. I, pp. 21-33.

Heller, C.

1870. Untersuchungen über die Crustaceen Tyrols. Ber. des medic. naturw. Vereins in Innsbruck. I Jahrg. pp. 67-96.

Herrick, C. L.

1882. Cyclopidae of Minn. with notes on other copepods. 10th Ann. Rep. Geol. and Nat. Hist. Sur. Minn. pp. 221-233.

1884. A final report on the Crustacea of Minn. included in the orders Cladocera and Copepoda. 12th Ann. Rep. Geol. and Nat. Hist. Sur. Minn. pp. 1-190.

1887. Contribution to the fauna of the Gulf of Mexico and the south. Mem. of Denison Sci. Assoc. Vol. 1, No. 1.

Herrick and Turner.

1895. Synopsis of the Entomostraca of Minn. 2nd Rep. State Zoologist of Minn. Geol. and Nat. Hist. Sur. Minn.

Hoek, P. T. C.

1876a. De Vrijlevende Zoetwater-Copepoden der Nederlandsche Fauna. Tijdsch. d. Nederl. Dierkund. Vereenig III, pp. 1-36.

1876b. Zur Kenntniss d. Frei-leb. Süsswasser Cop. d. Niederländischen Fauna. Niederl. Arch. f. Zool. Bd. 3, Heft. 2, pp. 126-142.

Jensen, S.

1905. Faunistik Fortegnelse over de danske FerksvandsCopepoder. Vidensk. Meddel. fra den naturh. Foren i Kbhvn. 1905. 
Joly N.

1883. Études complémentaires sur l'origine et le mode de formation de la glairine ou baregine dans les thermales sulfureuse des Pyrenées. Mem. de l'Academie des Sc. de Toulouse, pp. 118125.

Jurine, L.

1820. Histoire des Monocles qui se trouvent aux environs de Genève.

Koch, C. L.

1835-41. Deutschlands Crustaceen, Myriapoden und Arachnidem.

Lande, A.

1890. Materyjaly do Fauny Skorupiakow Widlonogich (Copepoda) Królestwa Polskiego. Wiłlonogi Swobodnie Zyjace. I. Rodzi-Cyclopy (Cyclopidae). Pamiet. Fizyjog. T 10.

1892. Quelques remarques sur les Cyclopides. Mem.

Soc. Zool. T 5, pp. 156-173.

Lehmann, Harriet.

1903. Variations in Form and Size of Cyclops brevispinosus. Herrick and Cyclops americanus Marsh. Trans. Wis. Acad. Sci., Arts, and Letters, XIV, pp. 279-298.

Lilljeborg, W.

1853. De crustaceis ex ordinibus tribus; Cladocera, Ostracoda, et Copepoda in Scania occurentibus.

1901. Synopsis speciorum huc usque in Suecia observatarum generis Cyclopis. Kongl. Svenska VetAkad. Handl. Bd. 35, No. 4.

Lubbock, J.

1863. Notes on some new or little known species of freshwater Entomostraca. Trans. Linn. Soc. Lond. XXIV.

Marsh, C. D.

1893. On the Cyclopidae and Calanidae of Central Wisconsin. Trans. Wis. Acad. Sci., Arts, and Letters, IX, 189-224. 
1895. On the Cyclopidae and Calanidae of Lake St. Clair, Lake Michigan and certain of the inland İakes of Michigan. Bull, Mich. Fish Com. 5.

1903. The plankton of Lake Winnebago and Green lake, Wis., Geol. and Nat. Hist. Sur. Bull. No. XII.

Matile, P.

1897. Contribution à la faune des Copépodes des environs de Moscou. Bull. Soc. Natur. Moscou, Annee 1897 , No. 1, pp. 113-139.

Pearse, A. S.

1905. Contributions to the Copepod fauna of Nebraska and other states. Trans. Amer. Mic. Soc. XXVI, pp. 145-160.

1906. Freshwater Copepoda of Mass. Amer. Nat. XL, pp. 241-251.

Poggenpol, M. J.

1874. List of the Copepoda, Cladocera, and Ostracoda of the environs of Moscow. Schr. d. Gesell. von Fremulen d. Naturwiss. zu Moskau. Bd. X Abth. 2 pp. 69-T\%. (Rnssian).

Pratt, E. M. and Hickson, S. J.

1898. The Entomostraca of Lake Bassenthwaite. Ann. Mag. nat. Hist. Vol. 2, pp. 467-476.

Rehberg, H.

1850. Beitrag zur Kenntniss der freilebenden Süsswasser Copepoden. Abh. d. Natur. Ver. zu Bremen. Bd. VI, pp. 533-554.

1880. Weitere Bemerk. iiber d. frei-leb. Süsswasser Cop. Abh. d. Naturwiss. Ver. zu Bremen Bd. VII, Heft. I, pp. 61-67.

Richard, J.

1887. Liste des cladocères et des copépodes d'eau douce observés en France. Bull. de la Soc. Zool. de France T XII, pp. 156-164. 
1888. Cladocères et copépodes non marins de la faune francaise. Rev. Scientifique du Bourbonnais. I, $57-70$.

1891. Recherches sur le système glandulaire et sur le système nerveux des Copépodes libres d'eau douce, suivie d'une révision des espèces de ce groupe qui vivent en France. Ann. Sci. Nat. Zool. T XXI, pp. 113-256.

1893. Copépodes recueillis par M. le Dr. Theod Barrois en Egypte, en Syrie, et en Palestine. Rev. Biol. du Nord de la France. T. V, 1892-3.

1895. Contribution a la Faune des Entomostracés de la France. Feuille des jeune Naturalistes, Mai et Juin 1895.

1896. Sur la faune des eaux douces des Açores. Bull. Soc. Zool. de France 21, pp. 171-178.

Sars, G. O.

1863. Oversigt af de indenlandske Ferksvandscopepoder Forhandlinger i Videnskabs-Selskabet i Christiania. 1862. pp. 212-262.

Schmankewitsch, W.

11875. Einige Krebse der Salzsee und süssen Gewasser, und ihr Verhaltniss zu dem sie umgebenden Elemente. Schrift. d. neuruss. Gesells. d. Naturf. Bd. III.

Schmeil, O.

1891. Beiträge zur Kenntniss der freilebenden Süsswasser Copepoden Deutschlands mit besonderer Berïicksichtigung der Cyclopiden. Zeitschr. f. Naturw. Halle, Bd. 64, pp. 1-40.

1892. Deutschlands freilebende Süsswasser-Copepoden. I Theil, Cyclopidae.

Seott, Thomas.

1893. The land and fresh water crustacea of the district around Edinburgh. Part II, The Ostracoda and Copepoda. Proc. Roy. Phys. Soc. Edinburgh, Vol. 12, p. I, pp. $45-76$. 
1897. The imvertebrate fauna of the inland waters of Scotland. Part III Fifteenth Ann. Rep. of the Fishery Board for Scotland.

Scott, Thomas and Andrew.

1894. On some new and rare crustacea from Scotland. Ann. Nat. Hist. Vol. 13, pp. 137-149.

1895. On new and rare species of Copepoda from Scotland. Ann. Scot. Nat. Hist. Jan. 1895. pp. 28-35.

Scourfield, D. J.

1898. The entomostraca of Epping Forest, with some general remarks on the group. Essex Natural. Tol. X, pp. 193-210, 259-274, 313-334.

1903. Synopsis of the known species of British freshwater Entomostraca. II. Copepoda. Jour. Que kett mic. Club, VIII, pp. 531-544.

Sostaric, D.

1888. Prilog poznavanju faune slatkovodnih korepnjaka Hrvatske Rad jugoslavenske akademije znanosti i umjetnosti XCII, pp. 103 ?214.

Abbreviated translation in Steuer, 1899.

1899. Die Entomostraken der Plitvicer Seen und des. Blata-Sees (Croatien) gesammelt von Dr. R. Sturany (1895) Ann. K. K Naturh. Hofmuseums Bd. XIII, pp. 162-171.

Steuer, A.

1897. Copepoden und Cladoceren des süssen Wassers. aus der Umgebung von Triest. Verh. Zool. bot. Ges. Wien, Bd. 47, pp. 615-630.

1899. Die Entomostraken der Plitvicer Seen und des Blata-Sees. Ann. K. K. naturhis. Hofmuseums. Bd. XII, Heft 2-3, pp. 159-188.

Thallwitz, J.

1890. Entomostraken. 5th Jahresber. d. Ornithol. Beobachtungsstat Sachsen. pp. 75-80. 
Thomson, G. M.

1883. On the New Zealand Copepoda. Trans. and Proc. New Zealand Inst. Vol. XV, pp. 93-11'6.

Uljanin, W. N.

1875. Crustaceen von Turkestan. Schriften d. Gesellsch. v. Freunden der Naturwissensch. zu Moskau. Bd. XI, pp. 22-41.

Vejdowsky, F.

1882. Tierische Organismen in den Brunnengewässern von Prag.

Vosseler, J.

1886. Die freilebenden Copepoden Württembergs und angrenzender Gegenden. Jahresh. des Vereins f. vaterl. Naturkunde in Württeberg. 22 Jahrg. pp. 167-204. 
1116 Wisconsin Academy of Sciences, Arts, and Letters.

\section{EXPLANATION OF PLATE LXXII.}

Fig. 1. Cyclops ater; fourth swimming foot (x 120).

Fig. 2. Cyclops ater; abdomen of female (x 103).

Fig. 3. Cyclops ater; fifth foot (x 340).

Fig. 4. Cyclops ater; eleventh to fourteenth antennal segments of female (x 425).

Fig. 5. Cyclops ater; receptaculum seminis (x 321).

Fig. 6. Cyclops ater; antennule of female (x 103).

Fig. 7. Cyclops viridis var. americanus; fifth foot (x 340$)$.

Fig. 8. Cyclops viridis var. parcus; fifth foot (x 340).

Fig. 9. Cyclops ater; last three segments of female antenna (x 212). 
Trans. Wis. Acad., Vol. XVI.

Plate LXxII.
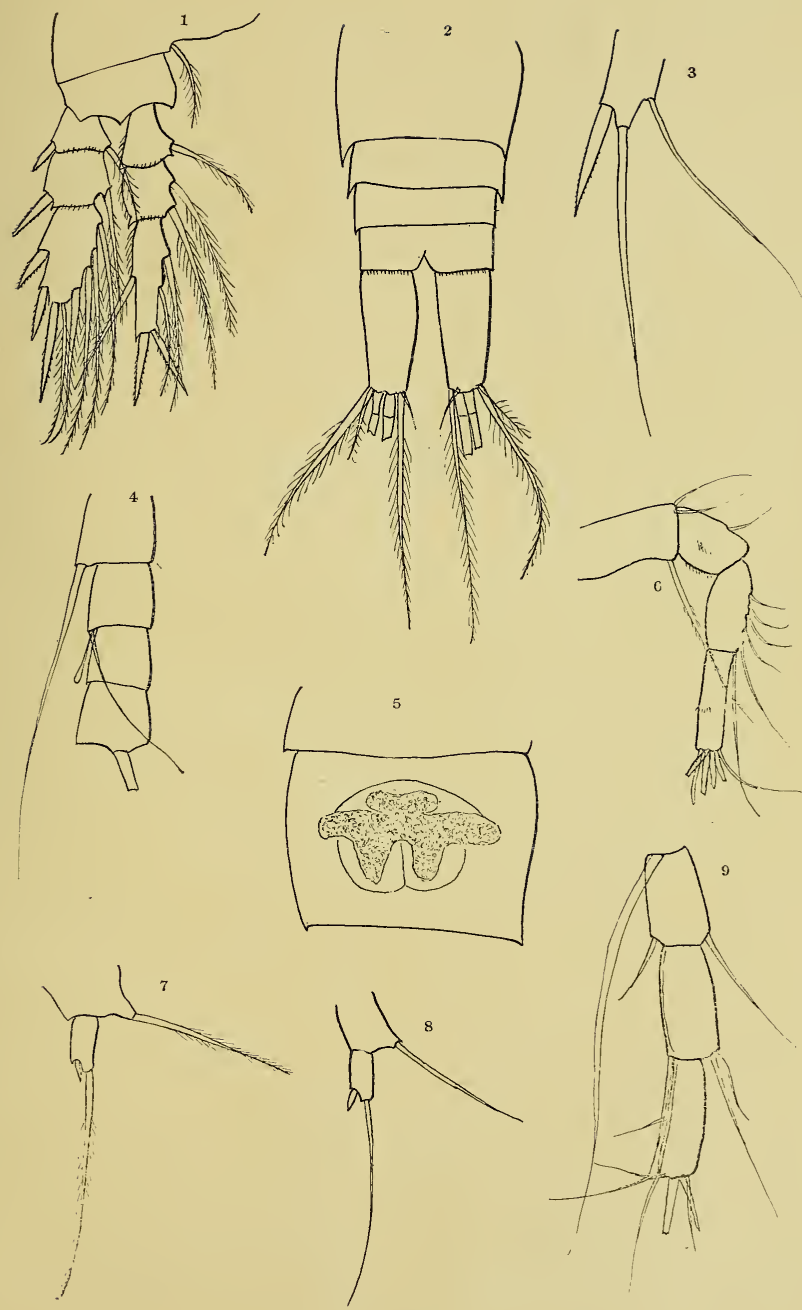



\section{PLATE LXXIII.}

o-S. \& A. -3 
1118 Wisconsin Academy of Sciences, Arts, and Letters.

\section{EXPLANATION OF PLATE LXXIII.}

Fig. 1. Cyclops bicuspidatus; first antenna of female (x 212).

Fig. 2. Cyclops bicuspidatus; second antenna of female.

Fig. 3. Cyclops bicuspidatus; furca of female (x 340).

Fig. 4. Cyclops bicuspidatus; mandible (x 340).

Fig. 5. Cyclops bicuspidatus; outer maxillipede (x 212).

Fig. 6. Cyclops bicuspidatus; fourth swimming foot (x 212).

Fig. 7. Cyclops bicuspidatus var.; abdomen of female (x 103).

Fig. 8. Cyclops bicuspidatus; abdomen of female (x 103).

Fig. 9. Cyclops bicuspidatus; labrum (x 475).

Fig. 10. Cyclops bicuspidatus; fifth foot (x 475).

Fig. 11. Cyclops bicuspidatus; fifth foot (x 475). 


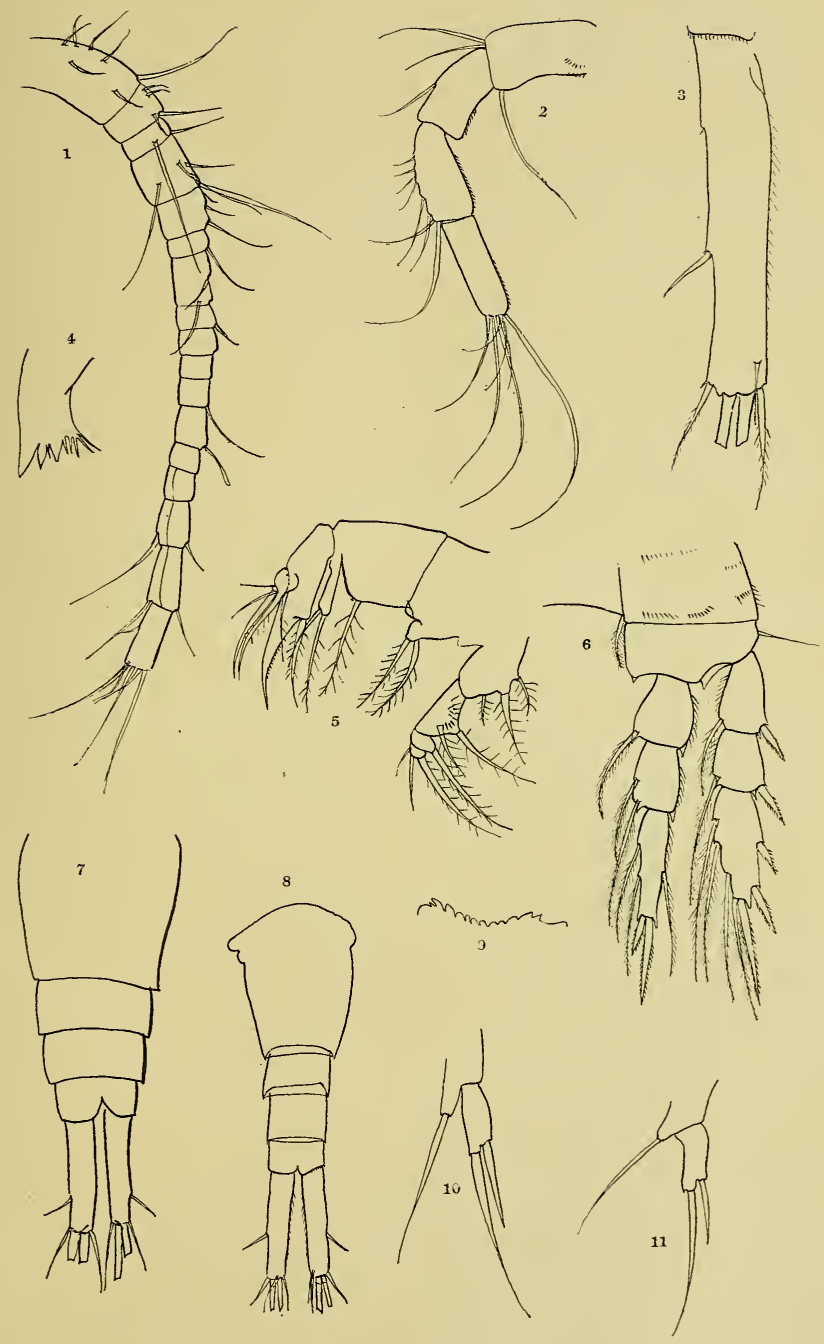



Marsh-North American Species of Cyclops. $\quad 1119$

PLATE LXXIV. 
1120 Wisconsin Academy of Sciences, Arts, and Letters.

\section{EXPLANATION OF PLATE LXXIV.}

Fig. 1. Cyclops viridis var. parcus; fourth foot (x 212).

Fig. 2. Cyclops viridis var. americanus; receptaculum seminis (x 212).

Fig. 3. Cyclops Leuckarti; abdomen of female (x 103).

Fig. 4. Cyclops Leuckarti; second segment of outer maxilliped (x 212).

Fig. 5. Cyclops Leuckarti; second segment of outer maxilliped (x 212).

Fig. 6. Cyclops Leuckarti; second segment of outer maxilliped (x 212).

Fig. 7. Cyclops Leuckarti; receptaculum seminis (x 165).

Fig. 8. Cyclops Leuckarti; fifth foot (x 340).

Fig. 9. Cyclops Leuckarti; fifth foot (x 340 ).

Fig. 10. Cyclops Leuckarti; terminal segment of female antenna (x $340)$.

Fig. 11. Cyclops Leuckarti; inner maxilliped (x 212). 
Trans. Wis. Acad., Vol. XVI.

Plate LXXIV.

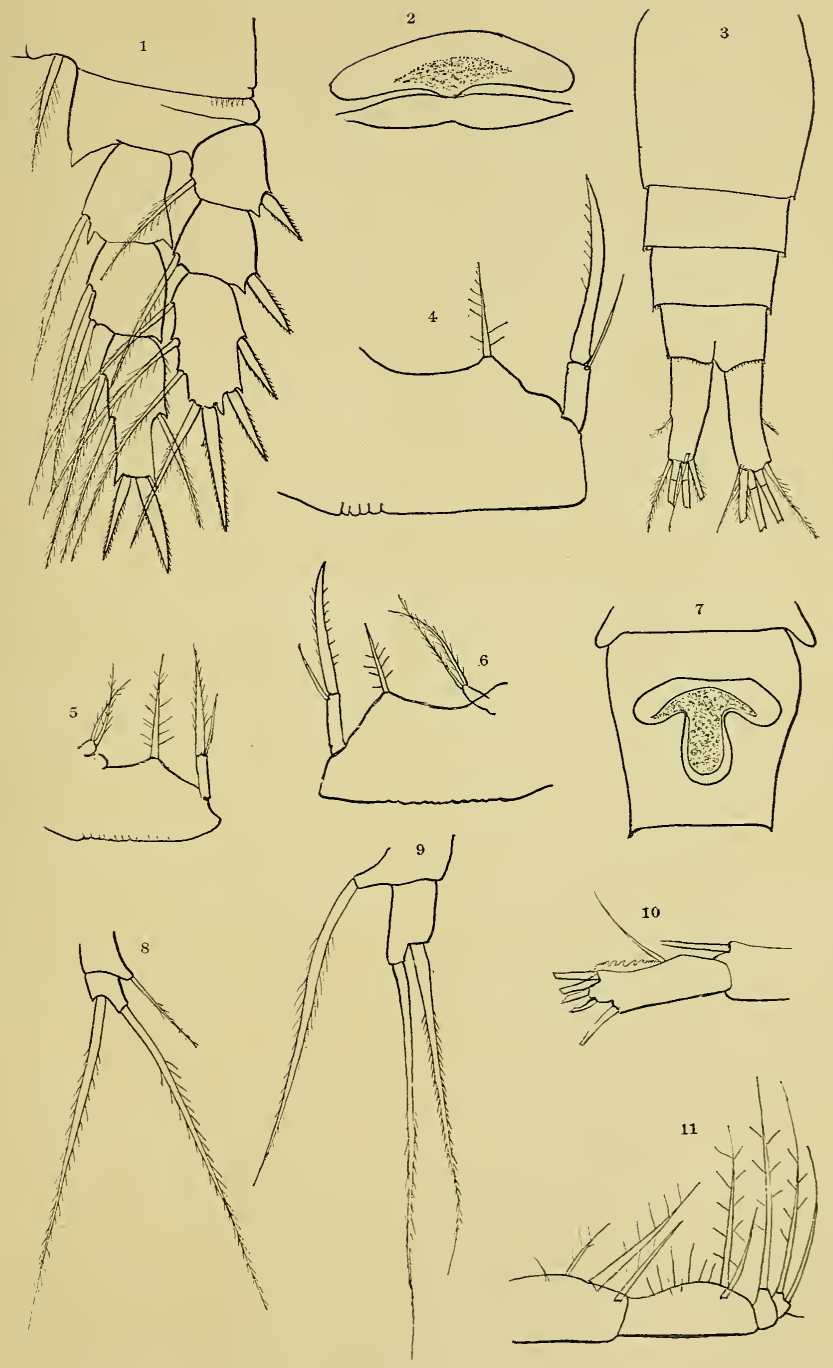



Marsh-North American Species of Cyclops.

1121

PLATE LXXV. 
1122 Wisconsin Academy of Sciences, Arts, and Letters.

\section{EXPLANATION OF PLATE LXXV.}

Fig. 1. Cyclops Leuckarti; fourth foot (x 212).

Fig. 2. Cyclops Leuckarti; twelfth to fifteenth antennal segments of female (x 300).

Fig. 3. Cyclops Leuckarti; second antenna (x 212).

Fig. 4. Cyclops tenuis; fifth foot (x 340).

Fig. 5. Cyclops tenuis; abdomen of female ( $\mathrm{x} 212$ ).

Fig. 6. Cyclops tenuis; labrum (x 475).

Fig. 7. Cyclops tenuis; antenna of female (x 120).

Fig. 8. Cyclops tenuis; cephalothorax and abdomen of female (x 70).

Fig. 9. Cyclops tenuis; receptaculum seminis (x 212). 


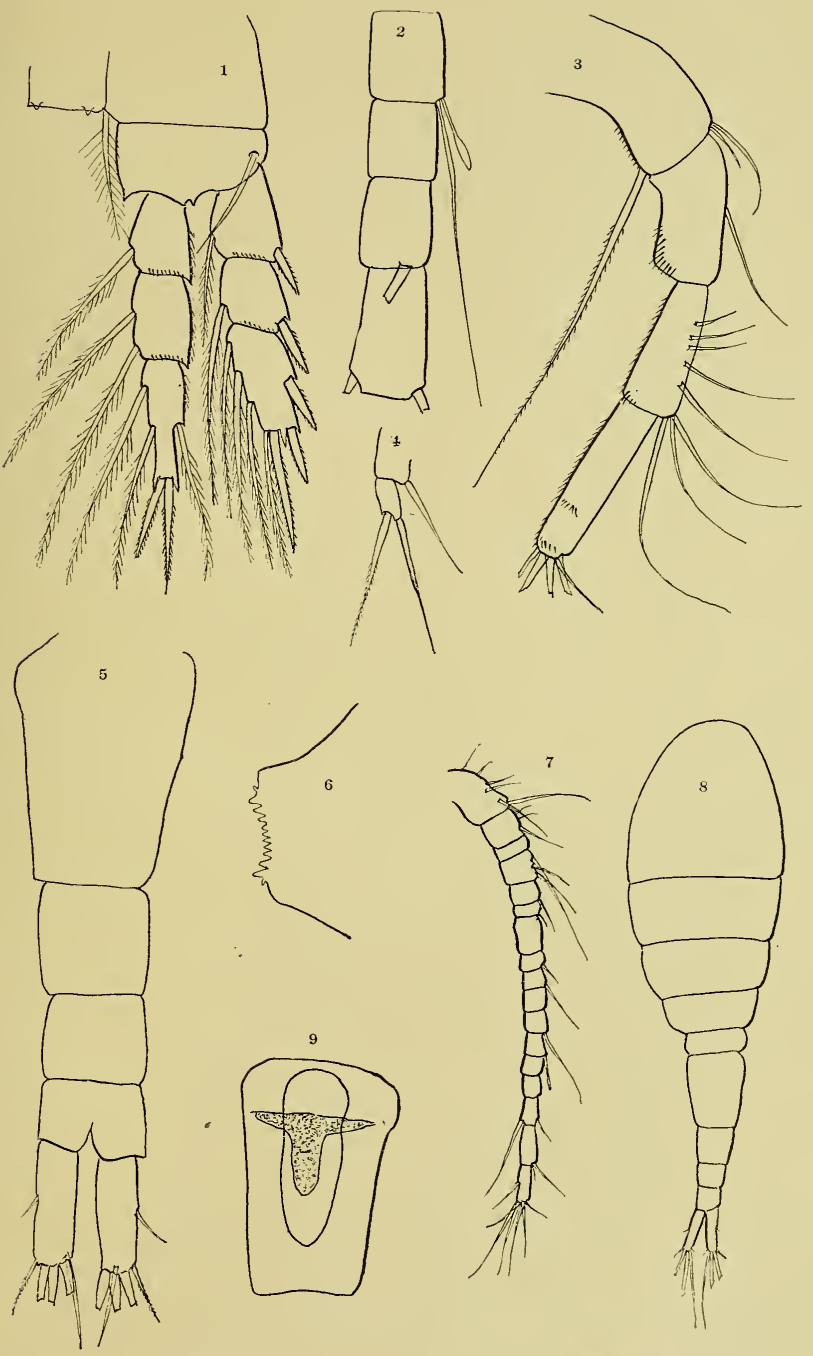



Marsh-North American Species of Cyclops. 1123

PLATE LXXVI. 
1124 Wisconsin Academy of Sciences, Arts, and Letters.

EXPLANATION OF PLATE LXXVI.

Fig. 1. Cyclops albidus; terminal segment of endopodite of fourth foot (x 340).

Fig. 2. Cyclops albidus; eleventh to fourteenth segments of antenna of female (x 212).

Fig. 3. Cyclops albidus; fourth foot (x 212).

Fig. 4. Cyclops albidus; inner maxillipede (x 162).

Fig. 5. Cyclops albidus; abdomen of female (x 103).

Fig. 6. Cyclops albidus; fifth foot (x 340).

Fig. 7. Cyclops albidus; second antenna (x 212).

Fig. 8. Cyclops albidus; sixteenth and seventeenth segments of antenna of female (x 216).

Fig. 9. Cyclops albidus; receptaculum seminis (x 212). 


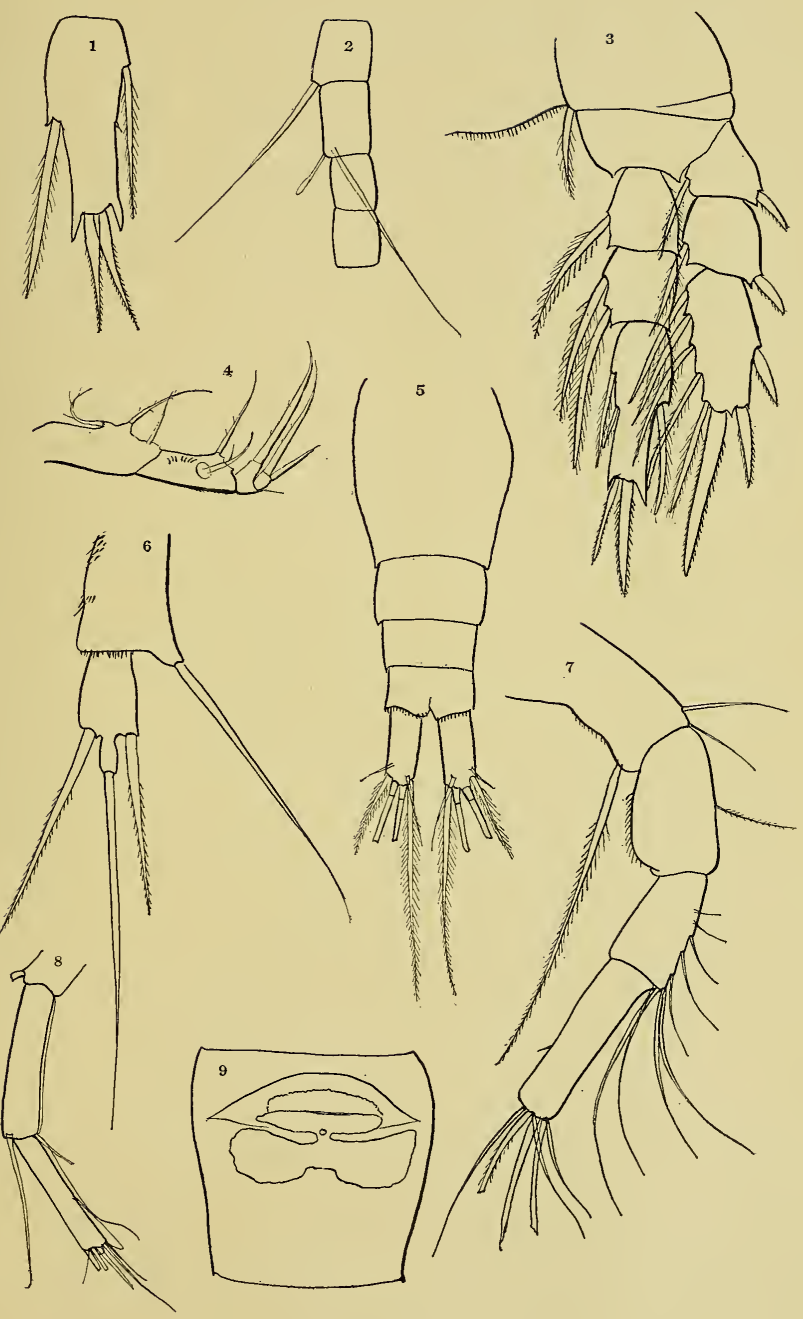



Marsh-North American Species of Cyclops. $\quad 1125$

PLATE LXXVII. 
1126 Wisconsin Academy of Sciences, Arts, and Letters.

\section{EXPLANATION OF PLATE LXXVII.}

Fig. 1. Cyclops fuscus; abdomen of female ( $\mathrm{x} 103$ ).

Fig. 2. Cyclops fuscus; terminal segment of endopodite of fourth foot (x 212).

Fig. 3. Cyclops fuscus; segments eight to fourteen of antenna of fomale (x 214).

Fig. 4. Cyclops fuscus; segments fifteen to seventeen of antenna of fomale (x 212).

Fig. 5. Cyclops fuscus; second antenna (x 212).

Fig. 6. Cyclops fuscus; receptaculum seminis (x 168).

Fig. 7. Cyclops fuscus; first segment of antenna of female (x 212). 
Trans. Wis. Acad., Vol. XVI.

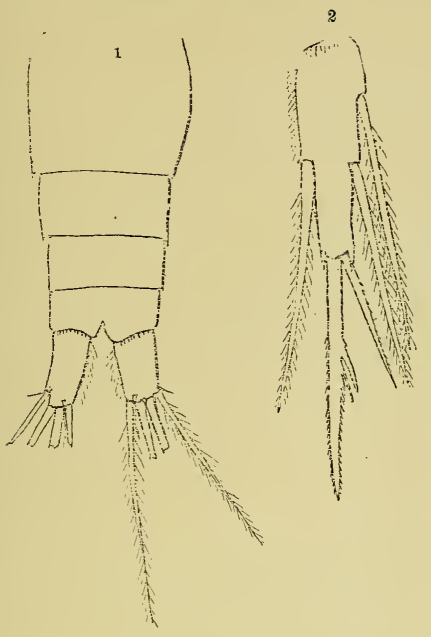

Plate LxxyII.
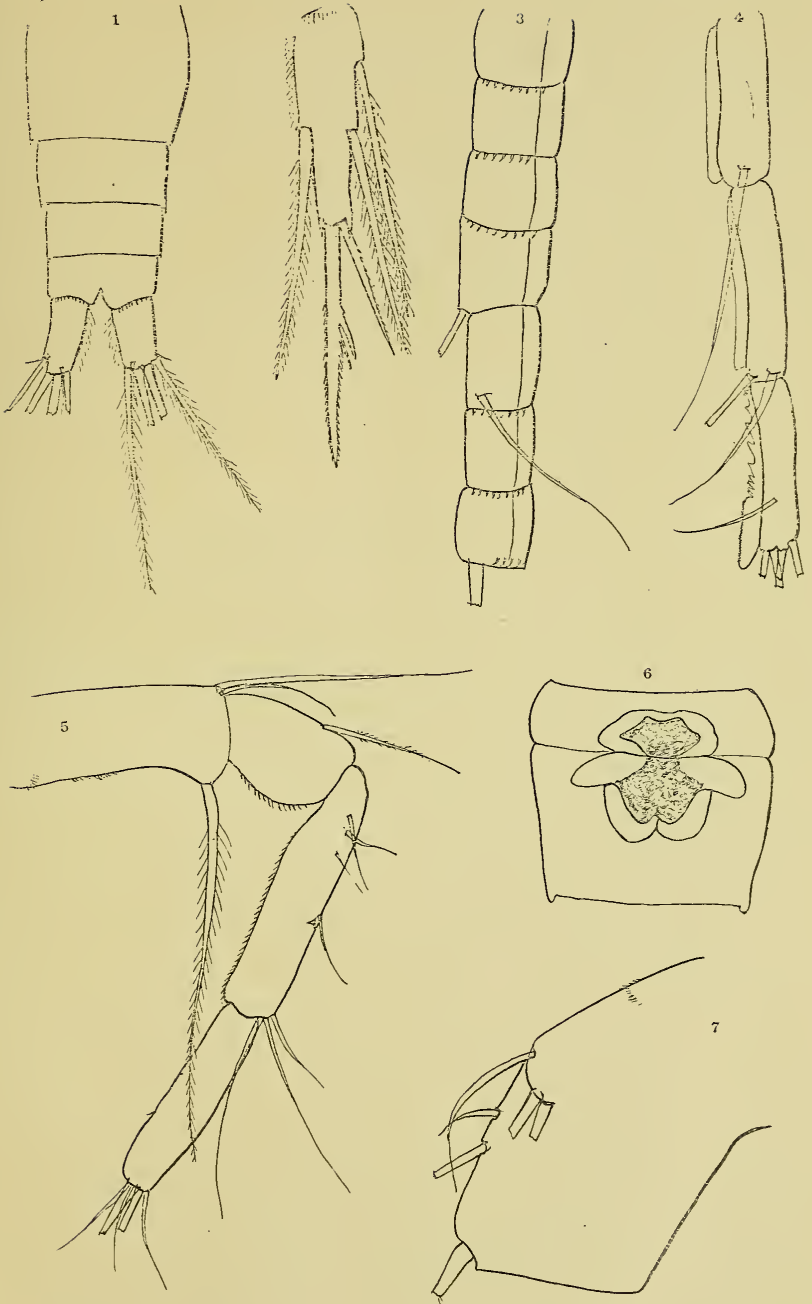

Marsh-North American Species of Cyclops. 1127

PLATE LXXVIII. 
1128 Wisconsin Academy of Sciences, Arts, and Letters.

\section{EXPLANATION OF PLATE LXXVIII.}

Fig. 1. Cyclops modestus; female (x 103).

Fig. 2. Cyclops modestus; first antenna of female (x 212).

Fig. 3. Cyclops modestus; fifth foot (x 340).

Fig. 4. Cyclops modestus; abdomen of female (x 212).

Fig. 5. Cyclops serrulatus; fifteenth, sixteenth, and seventeenth segments of antenna of female (x 340$)$.

Fig. 6. Cyclops serrulatus; abdomen of female, slender form var. elegans ( $\mathrm{x}$ 103).

Fig. 7. Cyclops serrulatus; abdomen of female, most common form (x 103).

Fig. 8. Cyclops serrulatus; fifth foot (x 475).

Fig. 9. Cyclops serrulatus; receptaculum seminis (x 212). 


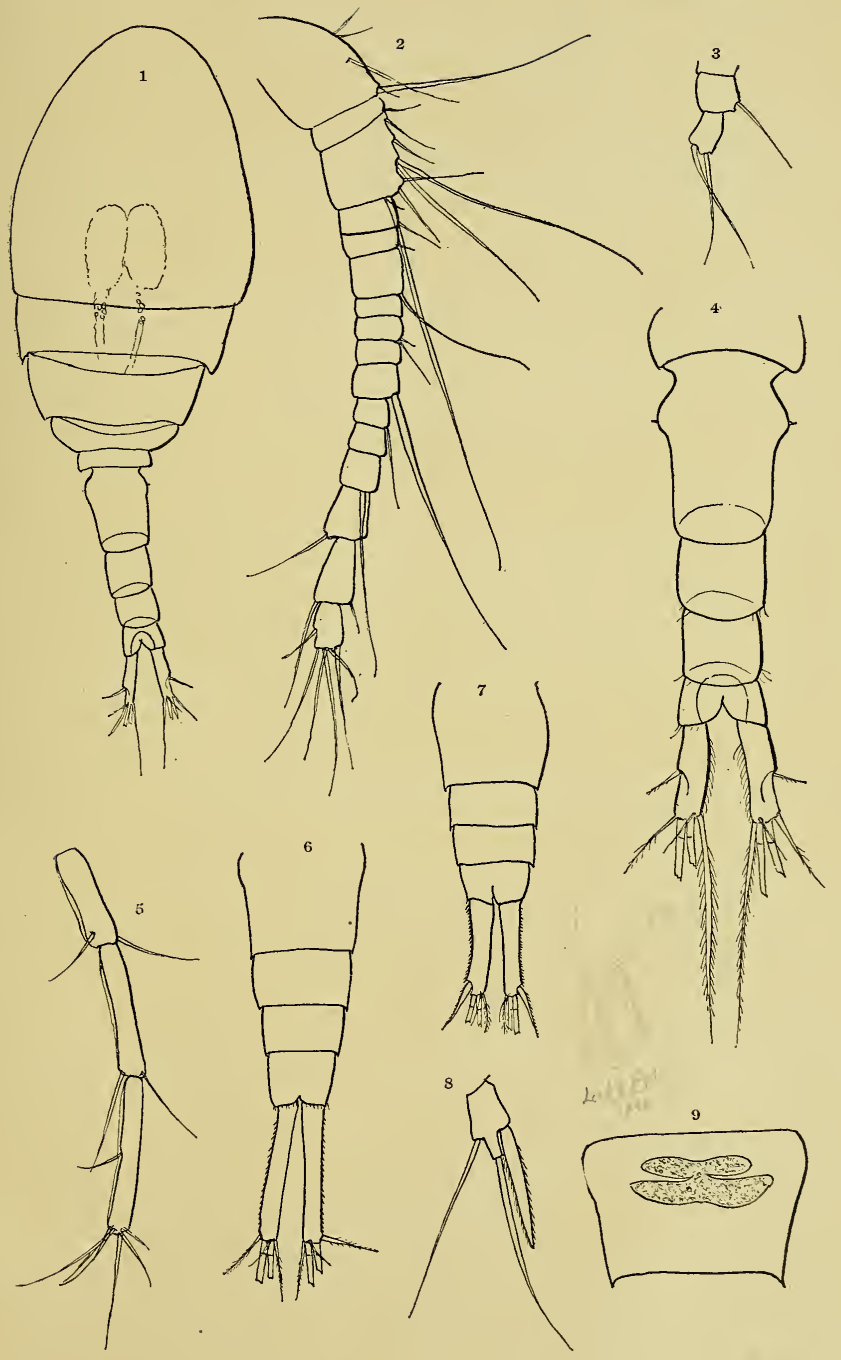





\section{PLATE LXXIX.}




\section{EXPLXANATION OF PLATE LXXIX.}

Fig. 1. Cyclops prasinus; abdomen of female (x 212).

Fig. 2. Cyclops prasinus; first antenna of female (x 212).

Fig. 3. Cyclops prasinus; fourth foot (x 340).

Fig. 4. Cyclops serrulatus; fourth foot (x 212).

Fig. 5. Cyclops tenuis; fourth foot (x 212).

Fig. 6. Cyclops viridis var. americanus; abdomen of female (x 103).

Fig. 7. Cyclops viridis var. brevispinosus; abdomen of female (x 103).

Fig. 8. Cyclops serrulatus; female (x 103).

Fig. 9. Cyclops phaleratus; fifth foot (x 340).

Fig. 10. Cyclops prasinus; fifth foot (x 475).

Fig. 11. Cyclops bicuspidatus var. navas; abdomen of female (x 103). 
Trans. Wis. Acad., Vol. XVI.

Plate LXXIX.

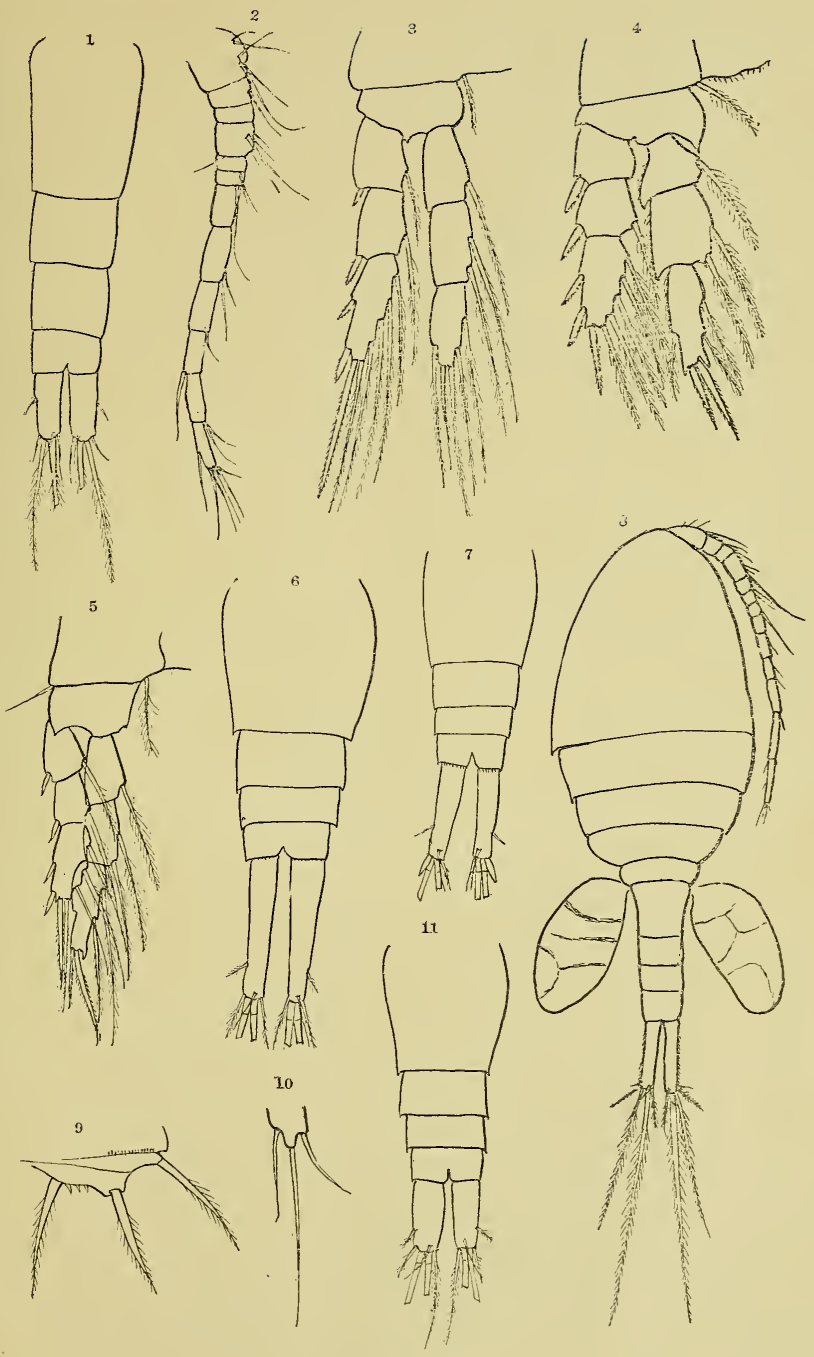



Marsh-North American Species of Cyclops. $\quad 1131$

PLATE LXXX. 
1132 Wisconsin Academy of Sciences, Arts, and Letters.

\section{EXPLANATION OF PLATE LXXX.}

Fig. 1. Cyclops phaleratus; female (x 58).

Fig. 2. Cyclops phaleratus; fourth foot (x 212).

Fig. 3. Cyclops phaleratus; antenna of female (x 212).

Fig. 4. Cyclops phaleratus; second antenna of female (x 340).

Fig. 5. Cyclops phaleratus; receptaculum seminis (x 212).

Fig. 6. Cyclops phaleratus; abdomen of male (x 103).

Fig. 7. Cyclops bicolor; second foot (x 340).

Fig. 8. Cyclops bicolor; fourth foot (x 340).

Fig. 9. Cyclops bicolor; fifth foot (x 340). 
Trans. Wis. Acad., Vol. XVI.

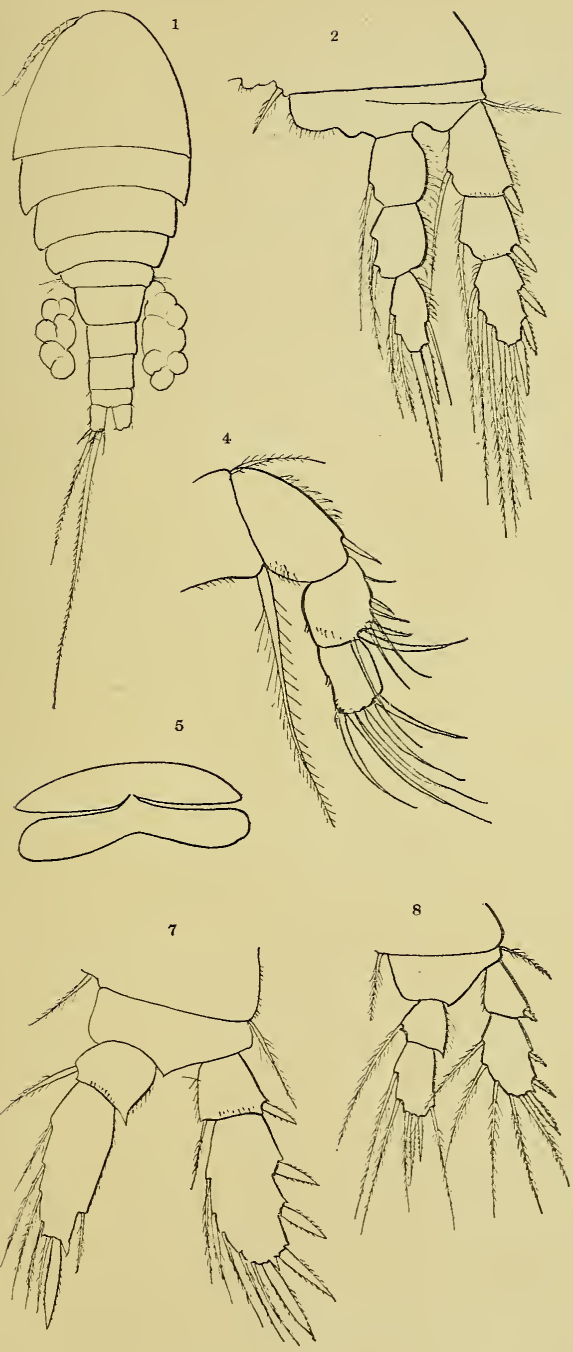

Plate LXXX.
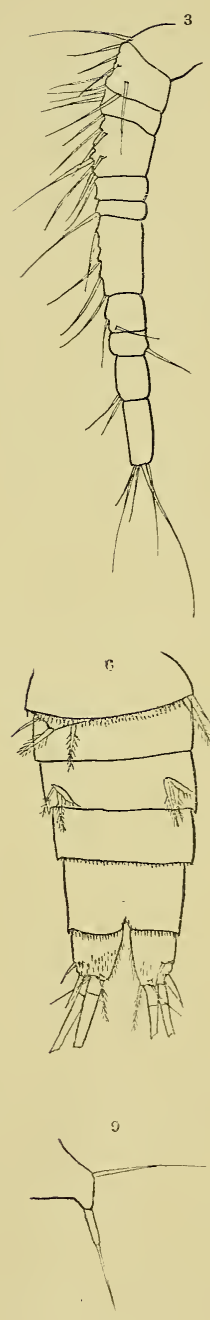

Marsh-North American Species of Cyclops. 1133

PLATE LXXXI.

10-S. \& A. -3 
1134 Wisconsin Academy of Sciences, Arts, and Letters.

\section{EXPLANATION OF PLATE LXXXI.}

Fig. 1. Cyclops bicolor; abdomen of female, dorsal surface (x 300).

Fig. 2. Cyclops bucolor; first antenna of female (x 340).

Fig. 3. Cyclops fimbriatus; female (x 72).

Fig. 4. Cyclops fimbriatus; fifth foot (x 340).

Fig. 5. Cyclops fimbriatus; fourth foot (x 348).

Fig. 6. Cyclops fimbriatus: furca (x 348).

Fig. 7. Cyclops fimbriatus: antenna of female (x 300$)$. 
Trans. Wis. Acad., Vol. XVI.

Plate LXXX1

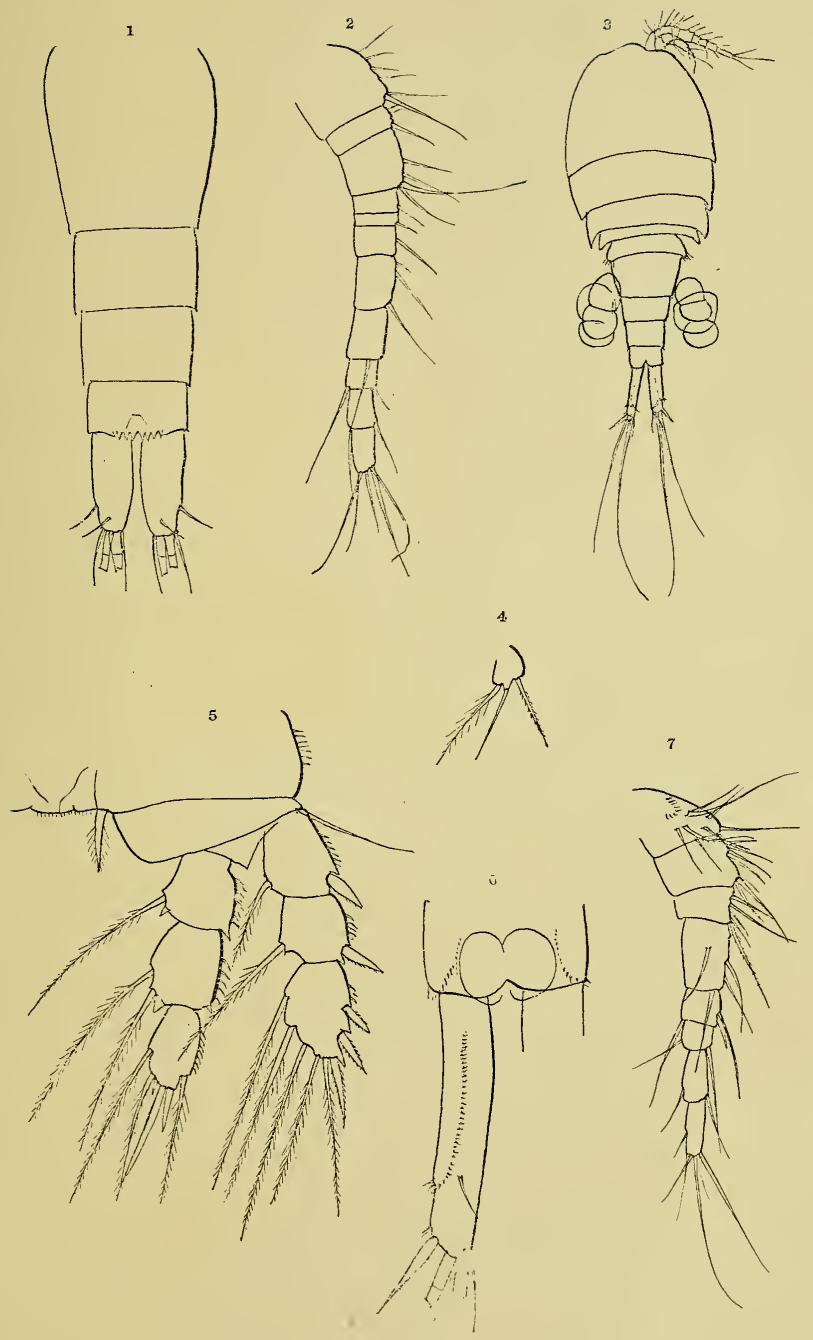





\section{INDEX OF SPECIES.}

Cyclops adolescens, 1099. aequoreus, 1106. agilis, 1094.

albidus, 1087.

americanus, 1073.

annulicornis, 1087. ater, 1071 .

bicolor, $\quad 1102$ bicuspidatus, 1078. brevicornis, 1072. brevisetosus, 1102. brevispinosus, 1073.

canthocarpoides, 1099 capilliferus, 1093.

Clausii, 1072, 1087. coronatus, 1090. crassicornis, 1104.

diaphanus, 1102 distinetus, 1087. Dumasti, 1106.

edax, 1082

Entzii, 1078 .

fimbriatus, 11:4. Fischeri, 1099.

fluviatilis, 1097.

Forbesi, 1079 .

gigas, 1072, 1078. gracilicornis, 1087. Gredleri, 1104. gyrinus, 1087.

helgolandieus, 1078

ingens, 1073.

insectus, 1073

lascivus, 1099

Leeuwenhoekii, 1081.

Leuckarti, 1081.

longicornis, 1097.

macmuroides, 1095 magniceps, 1106. magnoctavus, 1097. margoi, 1104.

minnilus, 1079 . modestus, 1093.
| Cyclops navus, 1078

odessanus, 1078.

oithonoides, 1081, 1087.

orientali, 1101.

parcus, 1073 .

pauper, 1104.

pectinatus, 1078, 1081.

pectinifer, 1094.

pentagonus, 1097.

perarmatus, 1099.

phateratus, 1099.

Poppei, 1104.

prasinus, 1097.

pulehellus, 1078. 108?.

quadricornis var. b, 1087.

quadricornis var. c, 1090.

Scourfeldi. 1082.

serratus, 1079

sermulatus, 1094.

serrulatus var. elegans; 1094.

serrulatus var. m.sntanus, 1094

signatus, 1087, 1090.

signatus var. annulicornis, 1088

signatus var. coronatus, 1090.

signatus var. fasciacornis. 108\%.

simplex, 1081.

tenuis, 1085.

tenuicornis, 1081, 1090.

Thomasi, 1078 .

uniangulatus, 1073.

varicans, 1101.

varius, 1095.

varius var. brachyurus, 1095. varius var. denticulata, 1095 . varius var. proximus, 1095. varius var. speratus, 1095. viridis, 1072 .

viridis var. americanus, $10 \pi 6$. viridis var. brevispinosus 1075 viridis var. ingens, $10 \% 5$. viridis var. pareus, 1076 . virido-signatus, 1088

Hemicyclops aequoreus, 1106.

Monoculus quadricornis albidus, 1097.

Monoculus quadricornis fuscus, 1090.

Monoculus quadricornis var. viridis, 1072. 


SMITHSONIAN INSTITUTION LIBAARIES

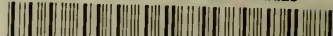

(3)

39088005797063 